\title{
Working Paper:
}

\section{Private Sector Delivery of Rural Piped Water Services in Bangladesh}

A Review of Experience, 2003-2015

August 2015 


\section{Abbreviations and Acronyms}

$\begin{array}{ll}\text { ADB } & \text { Asian Development Bank } \\ \text { BAMWSP } & \text { Bangladesh Arsenic Mitigation Water Supply Project } \\ \text { BMDA } & \text { Barind Multipurpose Development Authority } \\ \text { BOT } & \text { Build-Operate Transfer } \\ \text { BRWSSP } & \text { Bangladesh Rural Water Supply and Sanitation Project } \\ \text { BWSPP } & \text { Bangladesh Water Supply Program Project } \\ \text { CAPEX } & \text { Capital Expenditure } \\ \text { CBO } & \text { Community Based Organization } \\ \text { DANIDA } & \text { Danish International Development Agency } \\ \text { DPHE } & \text { Department of Public Health Engineering } \\ \text { DTW } & \text { Deep Tube Well } \\ \text { GOB } & \text { Government of Bangladesh } \\ \text { GPOBA } & \text { Global Partnership on Output-Based Aid } \\ \text { HYSAWA } & \text { Hygiene Sanitation and Water Supply Project } \\ \text { IBRD } & \text { International Bank for Reconstruction and Development } \\ \text { ICR } & \text { Implementation Completion Report } \\ \text { IDA } & \text { International Development Association } \\ \text { IRC } & \text { International Water and Sanitation Centre } \\ \text { JCA } & \text { Japan International Cooperation Agency } \\ \text { M\&E } & \text { Monitoring and Evaluation } \\ \text { MDG } & \text { Millennium Development Goals } \\ \text { MOF } & \text { Ministry of Finance } \\ \text { MOU } & \text { Memorandum of Understanding } \\ \text { MTR } & \text { Mid-term Review } \\ \text { NGO } & \text { Non-government Organization } \\ \text { O\&M } & \text { Operation and Maintenance } \\ \text { OBA } & \text { Output Based Aid } \\ \text { OPEX } & \text { Operational Expenditure } \\ \text { PAD } & \text { Project Appraisal Document } \\ \text { PID } & \text { Project Information Document } \\ \text { PMU } & \text { Project Management Unit } \\ \text { PPIAF } & \text { Public-Private Infrastructure Advisory Facility } \\ \text { PPP } & \text { Public Private Partnership } \\ \text { RDA } & \text { Rural Development Academy } \\ \text { RWSN } & \text { Rural Water Supply Network } \\ \text { SDF } & \text { Social Development Foundation } \\ \text { SME } & \text { Small and Medium Enterprise } \\ \text { SIPP } & \text { Social Investment Program Project } \\ \text { UNICEF } & \text { United Nations Children's Fund } \\ \text { UP } & \text { World Parishad } \\ \text { WBG } & \text { WSP Group } \\ \text { WTP } & \text { Water and Sanitation Program } \\ & \end{array}$




\section{Table of Contents}

Executive Summary

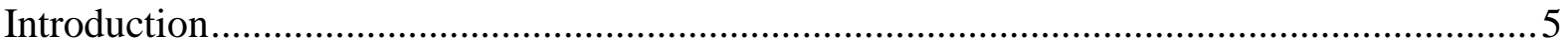

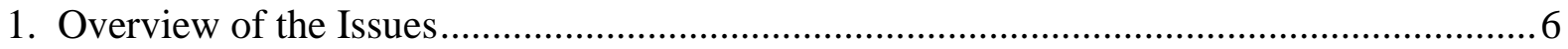

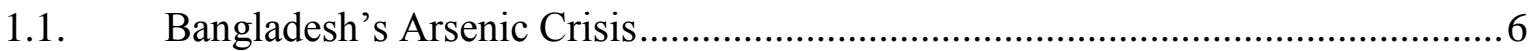

1.2. Preferred Technology - Deep Tubewells and Piped Networks ...........................6

1.3. Community Management Models as the Default Approach ................................

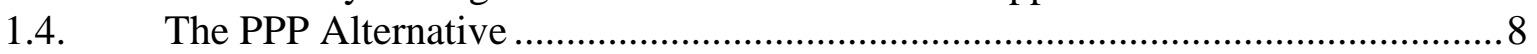

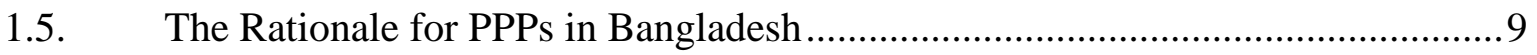

1.6. International Experience - The Role of Subsidies in PPPs ................................ 10

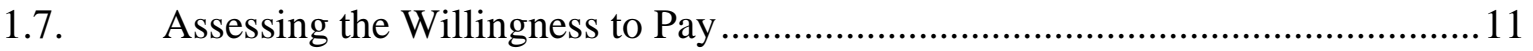

2. Piloting the Community Management Model .................................................................. 13

$2.1 \quad$ Department of Public Health Engineering (DPHE) Projects ............................... 13

2.2 Rural Development Academy (RDA) and Barind Multipurpose Development

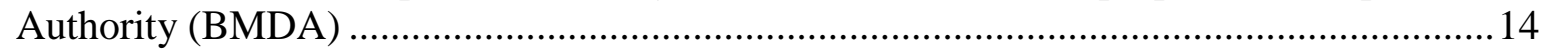

3. Designing and Testing the BOT Model - Early Studies and Pilot Projects ...................... 17



3.2 Bangladesh Arsenic Mitigation Water Supply Project (BAMWSP) .................... 18

3.3 Social Investment Program Project (SIPP-1) ................................................... 19

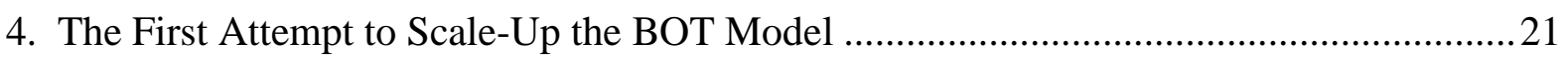

4.1 Bangladesh Water Supply Program Project (BWSPP) .....................................21

4.2 BWSPP Aftermath - Assessing the Lessons Learned........................................22

5. Subsequent Efforts to Scale Up and Evaluate the BOT Model .......................................26

5.1 Bangladesh Rural Water Supply and Sanitation Project (BRWSSP)..................26

5.2 Reviewing the BOT model in Bangladesh: BWSPP Monitoring Report.............30

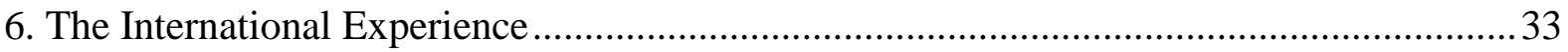

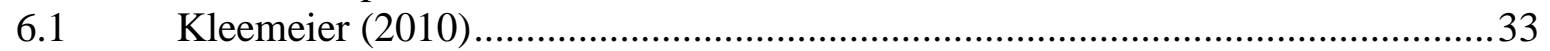

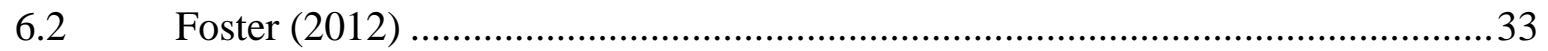

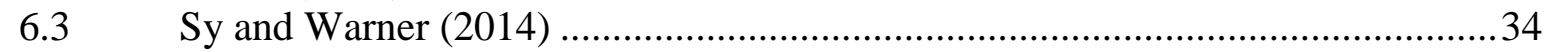

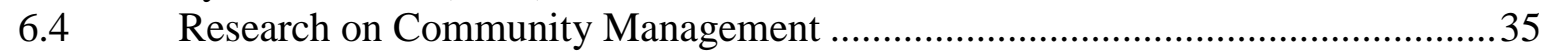

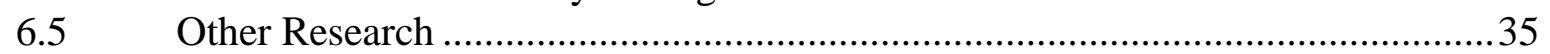

6.6 Lessons from the International Literature Review ............................................. 37

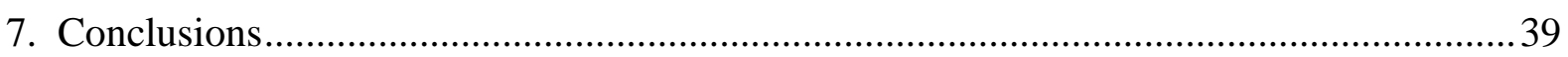

7.1 Lessons Learned About Implementing the BOT Model ....................................... 39

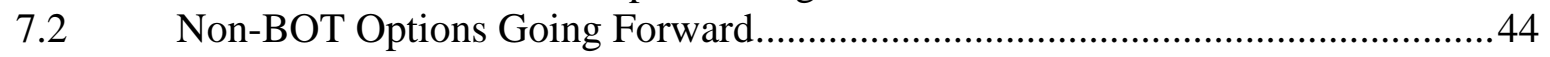

7.3 Two Longer-term Knowledge Objectives ...................................................... 47

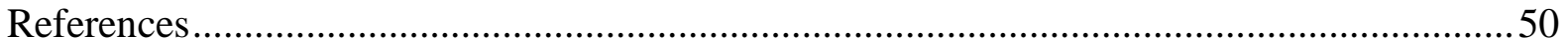

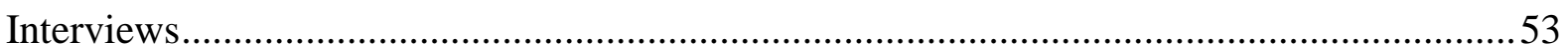

Boxes: 1. Standard Types of Public-Private Partnerships in the Water Sector .......................

2. GOB-WB Efforts to Roll-Out the BOT Model.....................................................11

3. Key Elements in a Sustainable Scaling Up of the BOT Model ............................22

4. Making the BOTs Work - Essential Program Elements .........................................40

5. Cost Components of Water Services .................................................................48

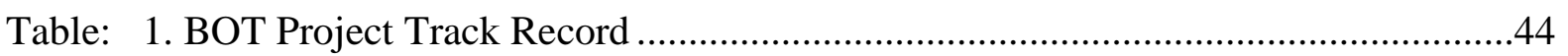




\section{Executive Summary}

\section{Introduction}

For the last 13 years, the Government of Bangladesh (GOB) and the World Bank have worked together to roll out a BOT model for rural piped water supply in the country. But the results of this collaboration have been disappointing. While the rationale for the PPP model was appropriate and warranted, except for a handful of schemes the model has generally not worked as expected, and efforts to scale up its use across large regions of the country have not been successful. This paper examines what occurred over the life of these projects, what lessons can be learned from this experience, and how these lessons should be used to guide the future interventions in respect of the provision of rural water supply in Bangladesh.

\section{Background}

The BOT model was originally employed as a way to deal with the widespread arsenic contamination of groundwater discovered in several locations across Bangladesh in the early 1990s. It was thought that a private operator model could cope with the costs and technical issues associated with the need to construct and operate the deep tubewells and piped distribution systems that could provide safe water to rural households.

Prior to the discovery of arsenic, most rural water supply schemes had been undertaken by communities with limited roles for government. The BOT model was seen as a mechanism to address the arsenic issue. It involved a limited role for government while expediting delivery through an enhanced role for the private sector. Given the limited success of community management models in rural water supply at that time, the BOT approach appeared to be perhaps the best option for mitigating the impact of arsenic at scale.

After a 2003 WSP willingness-to-pay (WTP) study found that customers might be willing and able to pay for such services if safe water could be delivered, two WB-supported projects tested a BOT design that covered capital costs with $40 \%$ private equity contributions, $10 \%$ community contributions, and 50\% OBA subsidies. User tariffs were expected to fully cover O\&M costs and allow private operators to recover their investments in 15 years. These projects were the Bangladesh Arsenic Mitigation Water Supply Project (BAMWSP), from 1998-2006, and the Social Investment Program Project (SIPP-1), from 2003-2007.

Because arsenic contamination affected huge areas of the country, the real value of the model was expected to be its capacity for scaling up service delivery. Two larger Bank-funded projects attempted to use the model in setting up hundreds of private operator schemes. These projects were the Bangladesh Water Supply Program Project (BWSPP), from 20052009, and the Bangladesh rural Water Supply and Sanitation Project (BRWSSP), from 20012-2017. Both projects carried out a variety of activities in the water sector beyond piped water supply which did deliver improved services. These have included efforts to improve non-piped water systems. But the efforts to roll out the BOT model in support of piped water supply were less successful, leading to significant funding and target reductions after midterm project reviews (MTRs). BWSPP reduced its BOT target from 300 schemes to 21. And while BRWSSP is still being implemented, after the MTR the BOT target was reduced from 125 schemes to 35 . 
A 2015 WSP monitoring report on the 21 schemes set up under BWSSP found ten to be nonfunctioning or badly mismanaged, and only four of the functioning schemes with any likelihood of recovering private investment by the end of their contract terms.

\section{Conclusions}

This review leads to three important questions. The first is what do we know now as a result of the experiences in utilizing the BOT model for the provision of safe water in rural areas in Bangladesh? In other words, what are the important lessons learned from these programs? The second question is what non-BOT options might be examined in the future? Finally, a third question is what additional analysis is needed to make informed decisions to address rural water supply constraints in Bangladesh in the future?

Lessons Learned About Implementing the BOT Model. The GOB-World Bank collaboration has shown that the BOT model has not been able to scale up the delivery of clean water to hundreds of localities to deal with widespread arsenic contamination of ground water. To better understand these results it might be helpful to identify the four essential, interdependent program elements necessary to achieve such a scale up.

- Program management. The overall management of the BOT roll-out processes was never robust enough to handle the hundreds of schemes planned for development. The GOB and the World Bank struggled to find an effective delivery model for setting up and staffing a project PMU to manage the complicated process of designing or evaluating schemes, and procuring sponsors for projects. Going forward with a BOT program, the capacity of a government implementing agency would have to be strengthened considerably before the project tries to start rolling out projects (rather than as part of the roll-out).

- Projects. Several characteristics of the schemes made them appear to be unattractive to potential sponsors. The costs associated with the delivery of water were also higher than expected and the need to pre-finance the capital costs of the schemes may have made the prospect of taking them on seem even less prudent to sponsors. Going forward with BOTs, it seems worth examining whether capital subsidies should be higher and whether some kind of operating subsidy is needed to facilitate the sustainability of schemes and attract competent sponsors.

- Private Operators. To date, the professional and entrepreneurial capacity of most of the selected private sponsors has not meet expectations. Individual entrepreneurs and private commercial enterprises have been far less attracted to the BOT schemes than NGOs, although this appears to be evolving in the latest round of sponsors under BRWSSP. NGOs have frequently agreed to act as sponsors, but have not been able to apply a commercial approach to their schemes. Poor management of the schemes has led to customer dissatisfaction, disconnections, and insufficient revenues, which in turn have led to further reduced service quality. Going forward, more upfront engagement is needed with potential private operators in order to better understand their interests and concerns related to managing water schemes. 
- Customers. Many prospective customers refused to connect to the networks, while existing customers were disconnected over time (either voluntarily or involuntarily). This was a complex and frustrating problem. An assessment of total family incomes demonstrated that most households could afford to pay for these water services. But their willingness to pay seems to have had the potential to sharply decrease as they weighed the costs involved against the quality of the water, the reliability and convenience of service, and the availability of alternative water sources. Going forward with BOTs, arsenic awareness in rural areas needs to be improved although this needs to be linked to service level improvements. It is also worth noting that programs like this tend to be more successful using a demand-responsive approach, meaning that end-users have a say in system designs, project siting, service levels, etc.

Non-BOT Options Going Forward. If alternative delivery models are to be explored, what other kinds of options might be available for providing safe water in Bangladesh's rural areas?

- Program Management. Whatever service delivery model is adopted, some kind of program management entity must administer the roll-out of schemes. As mentioned above, this might be dealt with via more and earlier technical assistance for government agencies or the use of non-governmental entities like RDA.

- Projects \& Operators. Another option in rural areas could be less ambitious kinds of PPPs, or schemes that combine subsidized community ownership and supervision with outsourced private management. A variety of stakeholders have recommended capital subsidies of $90 \%$ (or higher) for rural piped water schemes, as well as operating subsidies. Types of private operator contracts that would be supported by such subsidies could include the following:

- Management contracts. Government could build schemes and contract them out to private managers who would operate and maintain the systems, but be paid directly by government instead of via user fees. Several variations of this approach have been recommended in Bangladesh, including design-build-lease contracts and design-build-operate contracts.

- Clustering schemes. In order to achieve economies of scale, diversify operator risks, and possibly attract more professional sponsors like local engineering firms (or even international operators in partnerships or as sub-contractors with local firms), schemes could be clustered together to form much bigger projects. In effect, this would simply be using management contracts at scale with projects clustered to make them more attractive to private operators.

- RDA-style contracts. RDA has had some success in implementing its own version of PPP-type contracts, involving heavily subsidized schemes operated by local families or entrepreneurs on behalf of water user associations. Despite challenges, the RDA approach has demonstrated modest success in Bangladesh, especially when compared with the water delivery performance of alternative models. 
- Hybrid models. The emerging service delivery model in this subsector, which is most responsive to user demands and government mandates and constraints, may lie somewhere between BOT-type approaches and traditional community management schemes. In many cases this means fully outsourcing most service provision tasks to private operators, with asset ownership and final decisions on service levels and tariffs remaining with communities or local government.

- Professionalization contracts. In rural areas perhaps the first step should focus on existing schemes rather than new ones, regardless of how they have been structured. Professionalization contracts involve private firms contracted to help municipal water utilities implement Standard Operating Procedures for each functional area of the utility -- actual management control of the utility would not change hands.

- Customers. Perhaps rural areas in Bangladesh should be left to an enhanced community management model that builds on existing efforts undertaken by the government and other development agencies, with more emphasis on professionalization of services, contracting out operations, and long-term sustainability. The management of rural piped water schemes using more enhanced PPP-like approaches could be reserved for reasonably well capacitated local governments (UPs) in rural areas. But whatever service delivery model is chosen, if households better understood the risks of drinking water contaminated with arsenic, the willingness to pay for piped delivery of safe water could be much more robust.

Two Longer-term Knowledge Objectives. At least two additional issues need clarification in the Bangladesh context, regardless of which delivery model is chosen in rural areas.

- The first issue involves gaining a better understanding of how water pricing is done across Bangladesh, and the extent to which subsidies are available to supplement user fees. There are apparently no standardized methods for pricing or subsidy provision. Policies to regulate the sector and review and adjust tariffs are under development, but implementation modalities and capacity support are still in the early stages of review.

- The second issue involves the need for a compelling recommendation regarding the most cost-effective model for the delivery of safe water in rural areas, which the government ultimately can support with limited outside assistance. Ultimately this analysis would identify a sustainable, affordable model to deliver clean water, at scale, in rural areas. More specifically, this involves comparing the total life-cycle costs and benefits of the BOT model with various other delivery models promoted in rural areas by the government and other development agencies, or with delivery models used in other countries (such as the hybrid schemes emerging in West Africa). On the basis of a life-cycle analysis of this kind, the government can take its own informed decision about service delivery models, and can begin to take more ownership of the identified solutions. 


\section{Introduction}

This note explores the Bangladesh experience in implementing the widespread use of a 'private operator' model for building and operating rural piped water schemes. Since the early 1990s, the World Bank has, through a series of development projects, designed, piloted, and attempted to scale up use of the model as a mechanisms to address the very real issues of arsenic contamination and delivery at scale. The latest of these projects is still in implementation. The experience with these projects to date has been disappointing, and while a limited number of schemes are still in operation, the model has not been replicated in a large number of communities as intended and has not proved to be particularly sustainable.

Over this same period, the government and other development partners also have been using alternative methods to deliver the same kinds of services in rural areas. Some of these efforts seem to have been modestly successful. However, much of the evidence about the performance of these other models is anecdotal and there has been little rigorous analysis to compare the performance of these different models with the private sponsor approach.

As a consequence, not much clarity exists regarding which of the models works best in respect of rural piped water service delivery in Bangladesh. For this and other reasons, it would be premature to attempt to derive any authoritative conclusions about the success or failure of the private operator model versus other models.

However, it seems appropriate now to attempt a stock-taking exercise of what has been achieved since 2000 using the private operator model, so as to analyze and isolate the lessons learned to date. This paper attempts to do this on the basis of a desk review of existing World Bank literature, including project documents and research reports, coupled with interviews with key stakeholders and World Bank staff. It also makes use of non-Bank reports and studies, as well as research on attempts in other countries to implement this kind of approach for rural piped water schemes.

The first section of the paper provides an overview of the rationale and key issues associated with efforts to scale up a private operator model in Bangladesh. The second section reviews government efforts and those of its other development partners, to use a more traditional mode of service provision, involving community management. The third, fourth, and fifth sections review efforts by the government and the World Bank to design, test, and scale up a private operator model for service provision. A sixth section reviews some of the international research that provides insights into the use of such models in other countries and sectors. The paper ends with tentative conclusions about the experience in Bangladesh, lessons learned, and several options for further analysis. 


\section{Overview of the Issues}

\subsection{Bangladesh's Arsenic Crisis}

By the early1990s, Bangladesh had achieved remarkable success in increasing rural access to 'safe' water for domestic use, in ways that involved various forms of private sector participation. Over $90 \%$ of the rural population in Bangladesh was accessing the country's vast shallow water table using privately-owned hand pumps on shallow tubewells, 30-50 meters deep. The government had worked effectively with donors like UNICEF to build the capacity of the private sector to carry out the inexpensive drilling of such wells and the manufacture and distribution of suction pumps. Use of affordable products and services became widespread, and millions of rural households accessed water via house or yard connections that they installed and maintained. In all, over $75 \%$ of all tubewells have been privately constructed, making the Bangladesh program one of the world's largest and most successful in small-scale private provision of household water.

However, the country's apparent success with rural access to safe water ended abruptly in late 1993 with the findings by the Department of Public Health Engineering (DPHE) that vast stretches of the shallow water table were in fact heavily contaminated by naturally-occurring arsenic. Since then, the nature and extent of the contamination has been mapped in various ways. A number of studies have been undertaken to determine the extent of the contamination and the population impacted. For example, a 2010 epidemiological study found that as many as 77 million people, roughly half the country's total population at the time, had been exposed to toxic levels of arsenic, and that for the population sample studied over a ten-year period, more than $20 \%$ of the deaths were caused by arsenic (Argos, et al., 2010). The World Health Organization has notably called this arsenic contamination "the largest mass poisoning of a population in history" (WHO, 2002).

\subsection{Preferred Technology - Deep Tubewells and Piped Networks}

By the mid-1990s it was clear that Bangladesh faced a crisis over levels of arsenic contamination, which was putting millions of its people at risk. Even before the extent of the pollution was fully understood, the government began working with development partners to address the challenges associated with arsenic. Different technologies considered for arsenicsafe water sources focused on two fundamental approaches: (i) treatment to reduce arsenic levels, including various kinds of filtration; and (ii) technologies that facilitate access to safe water sources, such as deep tube wells, typically over 150 meters deep. The former is generally seen to be effective, but expensive. The latter, deep wells, connected to piped water supply networks and sometimes combined with treatment facilities, offered a relatively safe and convenient option, although still at higher costs than shallow wells. Such wells began growing in popularity as alternatives to other forms of water treatment in rural areas. One reason for the popularity of the piped schemes was that they could mimic the service standards of the shallow tubewells, with which rural populations had become comfortable. This meant that in order to ensure public acceptance wells had to be located in close proximity to a limited number of households. So wells had to be installed at a rate of one for 
every 10-15 households instead of for every 150-200 households, requiring more wells and greater costs than if the number of households per well were maximized.

Some rural pipe water schemes already existed in Bangladesh. By the early 2000s, about 90 such schemes had been established in rural areas, mainly by government agencies like DPHE. Most were operated by community water and sanitation committees. At least two regional government agencies, mainly focusing on rural agricultural development, were also already experimenting with community management systems for rural piped water schemes. The original focus of these agencies, the Rural Development Academy (RDA) in Bogra District and the Barind Multipurpose Development Authority (BMDA) in Rajshahi District, had been on deep tubewells for irrigation purposes in remote areas. In order to sustain these irrigation schemes financially, RDA and BMDA experimented with ways of using the irrigation water for domestic household use, via storage tanks and piped networks. As arsenic contamination problems emerged, both agencies saw the demand for domestic drinking water from such schemes increase dramatically. Water user committees were formed with the intention of managing operations and maintenance costs using tariff revenues.

\subsection{Community Management Models as the Default Approach}

Since the 1980s, the default model for water delivery in rural areas has been community management, which emerged with the help of donors largely in reaction to the challenges of centralized government to provide rural water services in many developing countries. Compared with government systems, community management has had some success, and the early accounts of its use by RDA and BMDA were positive (Bilu, 2009). But in the early 2000s, RDA and BMDA had not established many of these schemes, and the long-term sustainability of the schemes and their potential for scaling up was not yet clear. The major question at that time was whether or not community management could really handle the challenges associated with piped water schemes. Compared to the single point systems already widely used in Bangladesh, the deep wells and piped water systems were more complicated and expensive. They required more investment, reasonably good quality construction, operations and maintenance planning and expenditure, as well as general management expertise. None of these characteristics were prevalent in the existing system of rural water provision in the country because of the widespread focus on individual household hand pump schemes.

Additionally, from the global experience, it was already clear that community management schemes had shortcomings, some of which might cause serious problems if the GOB were to rely too heavily on this model for rolling out a major response to the arsenic pollution problem. Some of the identified shortcomings of the community management model include the following (WSP, 2010):

- Funding. Community management typically depends exclusively on public funding, which is often insufficient to meet demand. Because public funding is scarce, some communities are excluded from programs, or public funding is only available to initiate water activities and pay for construction, but is inadequate for later operations and maintenance, where funding is crucial. 
- Design and construction. Community-managed schemes can be designed and constructed by government agencies, community organizations, NGOs, or private contractors. However, the work and the installed equipment may not be of particularly good quality due to poor design, poorly managed construction work, or construction that leaves behind facilities that are too large, complex, or costly for communities to manage and maintain.

- Local commitment. Community management frequently declines in quality over time as the local population loses interest in managing, much less paying for, the operations and maintenance of the schemes. This is especially true for piped schemes that are too costly for community volunteers to sustainably manage on a non-profit basis. Some of the key assumptions underlying the community management model have been described as "myths," including notions about community cohesion, shared sense of ownership, willingness to form local organizations, and readiness to volunteer services (RWSN, 2010).

- Technical expertise. Community water managers almost always eventually need technical support, particularly for piped schemes. They usually cannot carry out rehabilitation of the facilities or anything beyond basic repairs. Furthermore, they often cannot adequately manage or oversee such activities carried out by others. Governments have usually been unable or unwilling to establish and sustain technical support services for communities.

- $\quad$ Sustained operation. The developing world appears to have a remarkably high number of cases of non-functioning rural water facilities, most of which were set up to be managed by communities.

\subsection{The PPP Alternative}

A good deal of effort has been spent on finding ways of improving community management models to minimize these kinds of problems (Moriarty, et al., 2013). Public-private partnerships (PPPs) are being piloted in some countries as one alternative to the community management of rural water schemes. Box 1 presents a standard typology of the types of private participation models that are most common in the water sector. 


\section{Box 1: Standard Types of PPPs in the Water Sector}

1. Brownfield concessions - a private entity takes over the management of an existing government-owned system and also assumes significant risk for investments needed to extend, complete, or rehabilitate the facilities. Compensation comes via user fees or government payments.

- Rehabilitate, operate, and transfer (ROT)

- Rehabilitate, lease or rent, and transfer (RLT)

- $\quad$ Build, rehabilitate, operate, and transfer (BROT)

2. Greenfield concessions - a private entity builds and operates a new facility for a period, and under conditions, specified in a contract. Compensation comes via user fees or government payments.

- $\quad$ Build, lease, and transfer (BLT)

- $\quad$ Build, operate, and transfer (BOT)

- $\quad$ Build, own, and operate (BOO)

3. Management and Lease Contracts - a private entity takes over the management of a government-owned system for a fixed period while ownership and investment decisions remain with the government.

- Management contract - The government pays a private operator to manage the facility. The revenue/ commercial risk remains with the government.

- $\quad$ Lease contract - The government leases the assets to a private operator for a fee. The private operator takes on the revenue/ commercial risk.

Source: Adapted from the World Bank and PPIAF, PPI Project Database

The expected advantages of the BOT model were summarized in the last of the World Bank project design documents advocating the use of the model for rural water provision in Bangladesh (World Bank, 2012):

- BOTs can bring some measure of private investment to the schemes, thereby easing financial pressures on governments;

- They can make possible commercial management of the schemes, which in turn can increase the ability of the schemes to cover operating costs and recover investments;

- They can help to ensure good quality design, realistic sizing, and construction by the same firm that will subsequently operate the system;

- BOTs can prevent disputes after construction about the quality of the infrastructure, which often occur when the company responsible for operating the system is not the same as the one responsible for construction;

- They can ensure complete operator familiarity with the system;

- They can save time in the contracting process; and

- Compared with typical community management approaches, BOT contracts can help ensure a more professional approach to operations and maintenance after construction is completed.

\subsection{The Rationale for PPPs in Bangladesh}

Given the growing realization of the severity of the arsenic issue by the late-1990s, coupled with challenges of public sector delivery at scale, the option of enhanced private sector participation appeared to be the best option for delivering safe water to large numbers of rural communities. At the time there was significant interest in private sector participation in 
public service delivery and PPPs were expected to multiply across infrastructure sectors around the globe. A large body of research was accumulating, which argued that private expertise and resources could help overcome delivery and service level challenges. In many countries, work was also being undertaken to develop domestic capital markets to attract local financing to infrastructure, particularly from pension funds and insurance companies who were seeking long term assets. Simultaneously there were efforts to expand the role of regulators to oversee private investment and management of infrastructure. And perhaps most significantly, private operators, primarily from Europe, were looking beyond their traditional borders and seeking opportunities in emerging markets.

All this was occurring at the same time existing delivery models in Bangladesh were being assessed to determine whether they could be used to scale up and address the arsenic challenge. The traditional model of shallow tubewells offered no protection from arsenic, deep tubewells were seen as prohibitively expensive for many rural households, and rural piped schemes development by NGOs and the public sector were not yet delivering at scale. These factors, combined with public sector capacity constraints and limited financing, indicated that PPPs were a viable option to deliver arsenic free water relatively quickly and at scale in rural communities in Bangladesh.

\subsection{International Experience - The Role of Subsidies in PPPs}

At the same time it was also becoming clear from global experience that for many kinds of infrastructure PPPs, some type of subsidization would be required on a longer-term, if not permanent, basis. The recognition of the need for subsidies in the water sector has since become widespread. Rural water provision involves poor end-users and in most developing countries is already dominated by grant funding from governments and donors. In this situation, 'partial commercialization' - involving a combination of public and private investment - is generally considered a realistic approach.

Partial commercialization would realize several objectives: (i) help borrowers establish credit track records, thereby helping them become more familiar with lender requirements and expectations; (ii) help lenders better understand the subsector and the mechanics of project finance (loans secured purely by revenue flows); and (iii) demonstrate to governments (and development partners) that some commercial finance can and should become a normal complementary component of financing in the subsector, in order to introduce financial discipline to the subsector, reduce the market distortions created by indiscriminate grant funding, and release some of the existing grant flows for more targeted purposes.

In Bangladesh in the early 2000s it seemed that partial commercialization might be achieved with subsidized BOT projects. In other words, the provision of partial subsidies to cover project capital costs might be able to leverage some equity contributions by private operators as well as by users, with ongoing O\&M costs covered by user fees.

The development community was already aware of project experiences in other countries that seemed to suggest that this model might work, particularly if subsidies could be paid out over time, as construction and service delivery outputs were achieved, rather than all upfront as in the case of many government subsidy programs (which shifted project non-performance risk 
to the government and away from sponsors/operators). By the early 2000s, performancebased approaches to subsidies were already being piloted by the WBG's newly established Global Partnership on Output-based Aid (GPOBA). Numerous OBA projects had been identified, and were well known to the development community.

One notable example, cited in project appraisal documents for the World Bank's first piped water BOT projects in Bangladesh, involved the use in Paraguay of performance-based subsidy payments to pilot small-scale water systems in some of its towns (World Bank, 2003). The project was noteworthy because not only did it involve private operators, it also required them to contribute investment funding - both rare elements of water projects in developing countries. Operators signed BOT contracts for projects financed through a combination of private financing and public subsidies that reimbursed operators only after they had connected households to the water system. Early evaluations suggested that the use of private operators facilitated more efficient operations, improved tariff collection levels (with revenues helping to pay off project debts), and helped keep government subsidies at minimum levels.

\subsection{Assessing the Willingness to Pay}

The possibility of using such an approach in Bangladesh - involving partial matching capital grants to mobilize community financing, partial performance-based capital grants to mobilize private financing and management, with O\&M costs covered by user fees - received a major boost with the publication in 2003 of a willingness to pay study, focused on the rural areas of the country.

The study, by the Water and Sanitation Program (WSP), concluded that rural people were willing to pay for piped water supplies of arsenic-free water. The research indicated that rural consumers were willing to pay a tariff that would both cover operation and maintenance, and contribute at least $10 \%$ toward capital costs. This study seemed to confirm claims by RDA and BMDA that community investment contributions needed for rural piped water projects were realistic. It also suggested that BOT models of private sector participation as implemented in countries like Paraguay might be sustainable and capable of being scaled up. The study played a major role in promoting a series of development projects undertaken by the GOB in collaboration with the World Bank to pilot and develop BOT financing and implementation modalities for the delivery of arsenic-free water in rural areas of Bangladesh (Box 2).

\section{Box 2: GOB-WB Efforts to Roll-Out the BOT Model}

1. Designing and testing the model - early studies and pilot projects:

- The 2003 Willingness-to-Pay Study

- Bangladesh Arsenic Mitigation Water Supply Project (BAMWSP) - 1998-2006

- Social Investment Program Project (SIPP-1) - 2003-2007

2. The first attempt to scale-up the model:

- Bangladesh Water Supply Program Project (BWSPP) - 2005-2009

3. Subsequent efforts to scale up and evaluate the model:

- Bangladesh Rural Water Supply and Sanitation Project (BRWSSP) - 20012-2017

- The BWSSP Monitoring Report - 2015 
The lessons learned about the BOT model in these various projects are assessed at the beginning of Section 3 below, following a preliminary review in the next section of some of the efforts made to pilot community management schemes in Bangladesh. 


\section{Piloting the Community Management Model}

\subsection{Department of Public Health Engineering (DPHE) Projects}

As experiments with the private sponsor model were being initiated in the early 2000s in Bangladesh, a number of other approaches were already underway, mostly involving government- or donor-funded construction of the facilities, with small community contributions, and community management of the schemes. Approximately 90 of these of schemes were constructed by DPHE using its own resources. Typically, prior to construction, some community mobilization took place, and user committees were formed to take over operations and maintenance after commissioning. DPHE's original intention was for communities to contribute $5-20 \%$ of the capital costs, but early reports indicate that communities on average contributed only 3-4\% (Ibrahim, 2004).

Similar models were used in piped water supply programs implemented with DPHE involvement and support from various donors. The efforts seem to have involved a broad collection of different stakeholders:

- UNICEF supported a small piped water program, for which implementation was delegated by DPHE to non-governmental organization BRAC (formerly known as the Bangladesh Rural Advancement Committee). The program involved community mobilization and the formation of user committees to carry out operations and maintenance, with ongoing support from BRAC, and a micro-credit program to help finance household water connections.

- DANIDA assisted with a DPHE piped water program designed to supply safe water to arsenic affected villages in coastal belt areas. This was a component of the Hygiene, Sanitation and Water Supply (HYSAWA) Project. Again, community involvement was a key part of the program, beginning with village needs assessments. User groups were formed and the community was expected to contribute 10 percent of the capital costs. A DANIDA project document noted that the World Bank was experimenting with a BOT model for rural piped water, but added that the experience with the PPP model would have to be evaluated, and if necessary modified, before it could be a part of the DANIDA-funded program (DANIDA, 2005, 10).

- In 2007, DANIDA created the HYSAWA Fund to act as a conduit for donor funding intended to support water, sanitation, and hygiene improvements implemented by local governments (Union Parishads) in rural and peri-urban communities. The Fund later used a combination of DANIDA and AusAid funding to build 237 rural piped water schemes, the ownership and operation of which was turned over to local governments.

- UNDP's Sustainable Environment Management Program (SEMP) supported a DPHE sub-project called the Community Water Supply and Sanitation Program (CWSSP). The program used a gradual approach to community involvement, beginning with a demonstration phase involving fully-funded schemes constructed by DPHE to create local demand. No contributions from the communities were collected during the demonstration phase, but in a follow-up phase communities were expected to pay 
$10 \%$ of capital costs. Down payments were to be made by communities for two-thirds of the capital contributions, with the balance to be paid in installments over a year. Operations and maintenance were the responsibility of the communities.

\subsection{Rural Development Academy (RDA) and Barind Multipurpose Development Authority (BMDA)}

As noted earlier, government-funded rural development research and training institutions like the RDA and BMDA had also implemented piped water supply schemes by the mid-2000s. Unlike the DPHE schemes, these were multipurpose projects designed to supply water for rice field irrigation, domestic water use, and other small-scale commercial activities such as livestock and nurseries.

The Barind area is located in Bangladesh's Rajshahi and Rangpur Divisions and is characterized by recurring water shortages. To address this issue, BMDA started sinking deep tubewells for irrigation purposes in 1985. Over time, nearby villages used the system for drinking purposes and the BMDA model has grown along these lines. The GOB, UNDP, and DANIDA have all supported the model, which includes management by a local farmers' cooperative. All costs are borne by the government and donors and there is no community contribution for capital expenditures. Pre-paid meters are used for both irrigation and drinking water charges and the fees are very low. No further contribution for O\&M is sought from the community and, in effect, there is no private participation in the BMDA schemes.

An important departure from BMDA's approach is RDA's effort to recover the capital costs. In the 1980s, RDA had begun investigating how to make deep tubewell irrigation schemes affordable in rural farming areas. They developed less expensive drilling and construction methods, buried pipelines to reduce water losses, initiated micro-credit programs to help households pay for water, and supplied training and technical assistance to help them develop commercial uses for water. They also made the schemes multipurpose so that they could generate revenue during periods when water from deep wells was not needed for irrigation. When the arsenic problem became apparent, RDA was already well advanced in its work on a potentially affordable technical solution.

The original RDA model used government funding to construct relatively small schemes, typically involving 30,000 litre storage tanks and 2-3 kilometres of pipe - sufficient for perhaps 400 household connections. Once local operators (referred to as village-based water user associations) made a down payment of $10 \%$ of the investment costs RDA contractors would install the system. The operator agreed to repay the outstanding capital costs within 10 years, presumably from the scheme's revenues, which were expected to also cover operations and maintenance. A WSP survey of piped water projects in Bangladesh (WSP, 2010) identified three types of operators involved in these schemes: (i) genuine village-level cooperatives, often organized as water committees by local civic leaders; (ii) regional, midsized NGOs, which often worked in multiple villages; and (iii) private entrepreneurs who operated the schemes for profit, often working through local cooperatives or committees as the schemes' real managers behind the scenes. 
By the time RDA presented its model at the World Bank's Water Week in February 2009, RDA described how it had used the approach in hundreds of villages in 55 districts, and added that the model was being replicated throughout the country by entities such as The Local Government Engineering Department (under the Ministry of Local Government, Rural Development and Cooperatives) and the Bangladesh Agriculture Development Corporation (under the Ministry of Agriculture). ${ }^{1}$

RDA's work with these rural schemes continues today. But by the late 2000s it had dropped the requirement that scheme owners be community groups or farmer cooperatives, acceding to the reality that many if not most of the schemes were owned and operated by affluent local families or entrepreneurs. (In RDA's view, their model should now be considered a PPP approach rather than a community management one.)

The schemes have had success in attracting private operators because the systems tend to be small and relatively inexpensive. WSP (2010) found that the total cost of the RDA schemes serving 300-400 households ranged from US\$13,000 to US\$30,000. (The BOT schemes aimed at serving twice as many households, often included treatment systems and meters, and could cost US $\$ 100,000$ to US\$150,000.) Plus, the financing terms have been attractive to operators, who must commit only $10 \%$ of the scheme costs before construction is completed and the scheme begins generating revenue, and then have 10 years to repay the balance (no interest is charged). (As subsequent sections of this paper indicate, BOT sponsors must prefinance all of the capital costs.) The RDA schemes have also been relatively successful in convincing households to connect to the systems and have generally kept operating costs low.

But shortcomings in the schemes have been acknowledged by RDA and documented by WSP (2010). The RDA schemes have not generally been successful in getting users to repay the capital costs of these schemes. As of 2011, none of the completed schemes had made a loan repayment beyond the initial $10 \%$ (RDA notes that scheme owners generally stop repaying after the first year or two). Although the scheme operators cannot become legal owners of the schemes until they repay $100 \%$ of the capital costs, this seems not to have incentivized them to keep paying. RDA says that most of the schemes cover their operating costs and about half of the 200 existing schemes are well maintained, but most of the schemes apparently do not generate profits. Tariffs have been too low to generate surpluses and consumers often resist efforts to increase prices beyond coverage of operating costs. RDA does not seem to have yet addressed the issue of poorly maintained schemes, even though most of these remain RDA assets.

A study of a small sample of RDA schemes published in 2010 confirmed that for most of the schemes reviewed no capital repayments were being made beyond the initial down payments. This was despite the fact that RDA reduced the money owed from $90 \%$ to $50 \%$ for some of the schemes. The schemes were generally not profitable, but also not affordable for all of the members of local communities, with poor residents relying on the charity of scheme

\footnotetext{
${ }^{1}$ At about the same time, BMDA claimed in press releases that it had developed more than 300 piped water systems across the country. These schemes also combined irrigation with drinking water provision, but were usually developed in collaboration with farmer cooperatives and typically involved $100 \%$ capital subsidies with no attempts at recovering capital costs.
} 
operators. The schemes were often operated by powerful local families who tightly controlled access to water, but sometimes lacked the professional skills necessary to adequately manage and maintain the systems (Fontein, et al., 2010). 


\section{Designing and Testing the BOT Model - Early Studies and Pilot Projects}

\subsection{The 2003 Willingness-to-Pay Study}

The effort to roll out BOT projects for the provision of rural pipe water really began with the "willingness-to-pay" study published by WSP in 2003. Because of its apparent positive endorsement of consumer readiness to pay cost-reflective tariffs, the study played a central role in facilitating a long process of BOT experimentation. When many of those experiments were not successful because of what turned out to be an unwillingness of households to connect or stay connected to the schemes, some observers looked back at the 2003 study and identified it as the beginning of problems. A 2010 WSP report noted that because the discrepancies between the study findings and actual demand were "so great," two conclusions were inescapable: “...willingness to pay studies should be viewed with some scepticism; and more study should be carried out on how rural consumers behave when faced with actual, not hypothetical choices" (WSP, 2010, p.13).

It is true that many economists have identified potential weaknesses of contingent valuation techniques, like those used in the 2003 study, in determining the willingness of consumers to pay for goods and services. Contingent valuation is often referred to as a stated preference model - people are asked how much they would be willing to pay for a particular non-market good or service. Many economists prefer to rely on revealed preferences expressed via binding transactions. The authors of the 2003 study were, however, well aware of these possible shortcomings, noting that it had not yet been established that "stated" willingness to pay would translate into actual willingness to pay and that institutional arrangements for service delivery would be critical in moving from principle to practice. The study pointed out that a contingent valuation survey was only one source of information for policy makers pilot projects demonstrating revealed preferences would be "equally important" (Ahmad, et al., 2003, xvii).

In fact, the study's conclusions regarding the connection between the desire for piped water and the desire for arsenic-free water revealed a somewhat more fragile willingness to pay than some later accounts suggest. Most of the respondents in the willingness to pay survey were not aware of the serious health implications of consuming arsenic-contaminated water (xi). Only about $35 \%$ of households in the sample had directly encountered arsenic contamination, and of those $41 \%$ were still using arsenic-contaminated shallow tubewells (xi). Of all the water supply technologies asked about in the survey, the respondents' overwhelming preference was for deep tubewells and piped systems (89\%). But the main reason for the preference was convenience rather than arsenic-free water.

About $70 \%$ of respondents perceived convenience to be the main advantage of these systems, presumably because piped systems most closely matched the desirable service levels of shallow tubewells and hand pumps. Respondents in the sample area expressed a willingness to pay about $1.9 \%$ of their monthly income for O\&M charges associated with domestic piped water connections, and about $3.2 \%$ of their annual incomes for the connections. But the desire for arsenic-free water was only a minute share of the overall desire for piped water. The study calculated that respondents were willing to pay only $0.2 \%-0.3 \%$ of their income for arsenic-free water. 
But the study was ultimately encouraging about the willingness to pay for piped water in the sense that the average willingness to pay was a small percentage of mean household income, and seemed adequate to cover the recurring operational costs of such schemes, as well as a reasonable share of capital costs. ${ }^{2}$ Based on these findings, the study concluded that piped water supply systems might well be affordable in many rural areas in Bangladesh. But the demand was based on an overwhelming desire for convenience rather than desire for arsenicfree water. In other words, the lack of alternative water sources was not a strong driver of willingness to pay in this case. Demand (and willingness to pay) would likely remain strong as long as piped systems came close to matching the reliability, convenience, and water quality (smell, taste, and appearance) of shallow tubewell hand pump systems. But if piped systems did not actually perform in that manner, many households were willing to seek other sources of safe water or even return to unsafe shallow wells, because they did not fully understand or recognize the health risks of arsenic-contaminated water.

A 2006 survey conducted in one of the country's arsenic-prone areas found that adoption of arsenic avoidance measures correlated with higher education levels, but not with exposure to information campaigns about the dangers of arsenic. So efforts by donors and development partners over the years to communicate warnings about the hazards of arsenic exposure have had little effect, at least through the mid-2000s, suggesting that such campaigns may have been poorly designed or under-resourced. The survey concluded that among poorly educated rural households, if access to safe drinking water seemed inconvenient or water quality (smell, appearance) seemed poor, households would drink arsenic-contaminated water instead (Aziz, et al, 2006).

\subsection{Bangladesh Arsenic Mitigation Water Supply Project (BAMWSP)}

The first World Bank-funded project that attempted to test the findings of the willingness-topay study was the Bangladesh Arsenic Mitigation Water Supply Project (BAMWSP), which was implemented over the 1998-2006 period.

Project summary. The project involved a US $\$ 44$ million credit, focused mainly on providing arsenic-free water to severely affected villages and municipalities, and raising public awareness of the arsenic problem. BAMWSP concluded that deep tubewells provided the most reliable technology for delivering safe water, but also confirmed that the option remained popular only if its use could approximate the convenience of shallow tubewells. Most of the wells installed by the project involved local consultants (mostly NGOs) advising specially-formed local user groups ("Ward Arsenic Mitigation Water User Groups") to plan and carry out construction of the wells.

To test the willingness to pay for safe water in rural areas, BAMWSP began a pilot activity to construct 13 rural piped schemes using a BOT model. Local private sponsors were engaged to build, partially finance, and operate the schemes (management would later be turned over

\footnotetext{
2 The study noted that beneficiaries of water supply projects in developing countries were often asked to contribute $10 \%$ to capital costs and meet the entire O\&M costs. In the early 2000s, India was using these guidelines to implement a rural drinking water program targeting about 70 million people. The Bangladesh WTP study indicated that poor households were willing to pay $13 \%$ of the capital costs for a domestic piped water connection; non-poor households were willing to pay 22\% (Ahmad, 2003, xiv).
} 
to the communities after a 15-year operating period). This BAMWSP model required investor-operators (referred to as "sponsors" because most were NGOs rather than private companies or individual entrepreneurs) to provide $40 \%$ of the investment costs. The investment would be recouped over 15 years of operations through tariff collections that would also pay for O\&M costs. The community would make an upfront $10 \%$ capital cost contribution, and BAMWSP would provide the remaining $50 \%$ as a subsidy paid out on a performance basis, using GPOBA funding, with sponsors reimbursed for outputs achieved and confirmed.

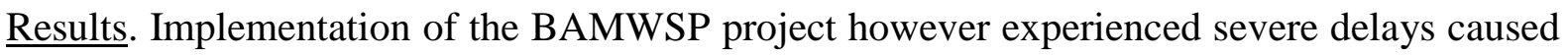
by project management problems. As a consequence of earlier management issues on previous projects, the BAMWSP's project management unit (PMU) had been set up separately from the Department of Public Health Engineering (DPHE), which with the exception of the three largest urban areas was the main agency charged with planning, designing, and implementing water supply and sanitation throughout the country. DPHE had implemented 90 or so active rural piped water schemes, and had traditionally been the default government location for all PMUs established to manage rural water projects funded by development partners. This was because DPHE was the main government implementing agency for rural water projects and had an extensive regional network of offices that could assist with water project implementation virtually anywhere in the country.

Without DPHE's regional support, BAMWSP made very slow progress under its project management arrangement, leading eventually to a US\$5 million grant cancellation and reintegration of the PMU into DPHE. As a result of these project management problems, by the end of the project in 2006 (which had been extended by one year), only one of the pilot schemes, for 1,100 households, was largely completed and the others were not yet under construction. So, while at the end of BAMWSP, the BOT approach still looked promising, it had not yet been thoroughly tested.

\subsection{Social Investment Program Project (SIPP-1)}

A second early Bank-supported project that also focused some of its resources on testing the BOT model for rural piped water supply was the Social Investment Program Project, which was implemented over the 2003-07 period, later extended to 2011 to help cope with the aftermath of the floods and cyclone of 2007.

Project summary. SIPP-1 was intended to use an IDA credit of US\$18.4 million to develop financial and institutional arrangements for improving access to local infrastructure services and implement small community-driven projects and social assistance programs. Project implementation was to take place in Jamalpur and Gaibandha, two of the poorest districts of Bangladesh at the time. The project would be managed by the newly created Social Development Foundation (SDF), a community development organization established under the Ministry of Finance.

Six rural piped water schemes were implemented in the two districts, using the BOT model. The target number of total households was about 3,600. SDF signed contracts with six sponsors (all NGOs) requiring them to contribute $40 \%$ of project costs and source $10 \%$ from 
local communities. SDF would contribute $50 \%$ of total costs using project funds. Tariff revenues would cover all O\&M costs. Sponsors were expected to build, design, and construct the systems, then operate them for 15 years in order to recover their costs.

Sponsors were allowed to select their project sites (usually villages or growth centers). They then conducted pre-feasibility studies, feasibility studies, and prepared final project proposals/business plans that analyzed technical, social, and environmental aspects of the proposed schemes. Financial aspects of the plans included analyses of construction and operation phases, financing plans, necessary tariff levels, tariff setting procedures, and tariff affordability analysis. Household surveys were conducted to gauge the willingness and ability of households to pay for their capital contributions and monthly tariff fees.

Most of these schemes also involved the creation of community-based organizations (CBOs) to work as voluntary representatives of the local user communities. The CBOs did not have equity stakes in the schemes, but worked with sponsors to carry out O\&M services and collect water bills. Above all, the CBOs were expected to monitor sponsor performance.

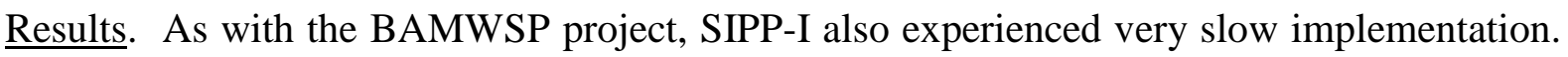
The requirement to carefully evaluate sponsors and their proposed projects led to a design and approval process that was long and complicated. Construction was expected to begin immediately on contract signing, but in practice was delayed by issues relating to land acquisition, the routing of pipelines, and the collection of the $10 \%$ community contributions for capital investment. Schemes were scheduled to be completed within 12 months, but project data shows that completion times actually varied between $14-60$ months, with an average of 36 months (Kamruzzaman, et al., 2012). The long completion periods subjected the schemes to cost escalations and as a consequence, discouraged households from connecting

The latter issue was a serious setback because when most of the systems were completed, relatively few households were connected. A 2014 review of the six projects completed by SDF showed that the schemes never achieved more than $66 \%$ of their targeted connections. This of course had a knock-on effect in terms of scheme viability. A basic assumption of the BOT approach (common also to the RDA model), was that water tariffs would be sufficient to cover O\&M costs, electricity bills, operator wages, sponsor service charges, and also meet equity return requirements. But project data shows that of the six schemes completed, only two were successful in generating adequate revenues to cover operating costs (one scheme stopped operation in 2010). The remaining schemes struggled to cover O\&M expenses, much less service charges, investment returns, or depreciation expenses. Poor revenue collection efficiency (averaging 88\%) exacerbated problems with revenues (SDF, 2014). 


\section{The First Attempt to Scale-Up the BOT Model}

\subsection{Bangladesh Water Supply Program Project (BWSPP)}

BAMWSP's unfinished schemes were transferred to the Bangladesh Water Supply Program Project (BWSPP), which began with an IDA grant of \$40 million for work over the period 2005-2009. The project was later extended to 2010.

Project summary. Planning for BWSPP reflected the government's sense of urgency regarding the need to address the arsenic problem, as well as its willingness to consider innovative approaches to safe water provision. BWSPP had been in planning as a way to dramatically scale-up the BOT model ever since the start of the BAMWSP pilots in 2003, and was already under implementation before BAMWSP actually reached completion. As a consequence, relatively little was known about the strengths and weaknesses of the BOT model. Clearly it worked in some pilot situations, but scaling-up the model in hundreds of villages at the same time was a vastly different and resource-intensive type of exercise.

In addition to components focusing on non-piped water supply and ways of improving the response to natural disasters, BWSPP's original design called for it to adjust and rapidly scale-up the BAMWSP BOT model by using it to construct piped water schemes in 300 villages. The project would provide technical assistance and 50\% capital grants to support private sponsors (entrepreneurs, co-ops, NGOs, etc.) to design, construct, and operate piped schemes for 15 years. (After this period a community organization was supposed to take over management from the private sector sponsor.)

Sponsors would provide $40 \%$ of the investment as equity and would collect an additional $10 \%$ from the local community. A performance-based OBA approach was to be used in paying out the $50 \%$ subsidy, with sponsors reimbursed for outputs achieved. Because the OBA approach required sponsors to pre-finance investments for which subsidies would ultimately be paid, as well as raise their own equity contributions for the schemes, the project also intended to develop some kind of financing mechanism, such as a partial credit guarantee, to interest local banks in making long-term loans to sponsors to help cover these pre-financing costs.

As with the SIPP project, BWSPP developed and used a very thorough process for evaluating and recruiting sponsors to carry out the planning, implementation, and operation of the rural piped schemes. The key steps included the following:

- Request Expressions of Interest,

- Prequalify interested respondents,

- Sign a Memorandum of Understanding (MoU),

- Approve an Inception Report (proposed village, socioeconomic characteristics, proposed team, water quality report, etc.),

- Approve a feasibility study,

- Approve a design study,

- Sign a grant agreement, and

- Authorize construction to begin. 
Results. By the time the mid-term review of BWSPP began in 2007 its implementation had come to a standstill due mostly to poor project management. Unlike the two earlier projects involving BOTs, BWSPP's PMU had been moved back into DPHE at the start of the project. But as the ICR later acknowledged, this had not helped. The PMU still lacked the personnel and skills needed to manage the project, and did not have the capability to drive the above listed activities for evaluating and recruiting sponsors. The project was restructured, the original $\$ 40$ million credit was reduced to $\$ 18.5$ million, and many of the original performance targets were cut back or removed. Activity on rural piped water supply was trimmed from the initial target of 300 villages to 21 villages (13 of which were the original BAMWSP schemes). The number of targeted household beneficiaries was decreased from 100,000 to 25,000 . Sponsor equity requirements per scheme were lowered from $40 \%$ to $20 \%$ and the total subsidy per scheme was increased to $70 \%$. (The requirement that communities contribute $10 \%$ was retained.) The process of developing a financing mechanism for system sponsors never really began and was dropped at the time of project restructuring.

When the project ended, the revised target of 21 piped schemes had been met, with NGOs making up most of the sponsors contracted to construct and operate the schemes. Each scheme comprised two production tubewells, one pump house, a pump and pumping equipment, storage tank (either ground or overhead), piped distribution network, and consumer connections. Most schemes also included treatment works, and by the end of the BWSPP project, several of the schemes had begun adding household meters. Construction on all the schemes had started, several had also begun operations, but only two had track records of longer than three years. For those in operation, the duration of service delivery was about six hours a day. Approximately 10,000 households ultimately benefitted from this project component, as against the revised target of 25,000.

\subsection{BWSPP Aftermath - Assessing the Lessons Learned}

By the time planning for a BWSPP successor project began in 2010, some important lessons had been learned about scaling up BOT models for rural piped water supply. Box 3 below draws from Bank documents some of the key elements recognized as necessary for successfully scaling up a model of this kind.

\section{Box 3: Key Elements for a Sustainable Scaling Up of the BOT Model}

1. Program Management: A cost-effective and timely process needs to be in place for identifying, evaluating, and contracting with multiple sponsors. For the GOB-WB BOT projects, this role would be played by a PMU using WB-approved procurement rules.

2. Sponsors: These are the "private partners" in the BOT subprojects, selected via the PMU's procurement process, who must be capable of selecting appropriate sites, preparing viable projects, and ultimately supplying water services on a cost-reflective basis.

3. Projects: These are the BOT subprojects selected and developed by the sponsors. They must be commercially viable within the financial structure requirements and subsidy support arrangements proposed by the program and administered by the PMU.

4. Customers: Potential project customers must be willing and able to pay for reasonable quality water at acceptable service levels.

5. Regulation: Contract compliance must be monitored by or on behalf of the "public partner" in the BOT arrangement. Rules for tariff setting and service quality should be clear and authoritative.

6. Technical Support: Various actors in a BOT program typically need technical support and capacity building - the actors can include sponsors, community groups, government managers, private sector financers, etc.

7. Evaluation: Data gathering and evaluation processes should be in place to aid regulators, program managers, as well as to channel lessons learned back into the overall program design. 
Program management. The BWSPP project approach had been complex and ambitious. The design taxed the ability of the PMU to manage key activities. Because the previous BAMWSP project had never fully tested this model, and the urgency of addressing the arsenic problem was so great, BWSPP was forced to both pilot test it and at the same time attempt to rapidly scale up its use. This ambitious objective was arguably justified given the urgency of the arsenic crisis, but it was especially ambitious given the level of difficulty in the approach, which included an arduous procurement responsibility (the overall project had hundreds of procurement packages pending at any given time) and a large collection of institutional partners. Multiple innovative project design components also contributed to the intricacy of BWSPP, including largely untested features such as (i) using private entities to construct and operate water facilities; (ii) attempting this in poor, rural areas; (iii) using performance-based (OBA) subsidy payments; and (iv) requiring small sponsors to find ways of pre-financing investments that would be covered by subsidy reimbursements only after outputs were certified as complete. One lesson learned from BWSPP was that if the BOT model was going to be rapidly scaled up, the approach needed to be simpler and more easily managed.

Nothing better demonstrated the overly complex character of the approach than the long and onerous scheme development process required before construction could begin. After the initial prequalification period, the number of months required to go from a signed MoU to a grant agreement required a median of three years for the 21 schemes (with one scheme taking $41 / 2$ years). The process was often delayed by factors such as: (i) poor project management of the process by the PMU; (ii) sponsors' difficulties in making capital contributions or in paying for various aspects of the process; (iii) problems in procuring land; (iv) the need for additional test drilling; and (v) price escalation.

Sponsors. While the initial interest by potential sponsors in the schemes seemed enthusiastic, according to the ICR at the time of bidding most private businesses and entrepreneurs concluded that full cost recovery was not possible and they did not participate. This left most of the schemes to NGOs, many of which were actively engaged in seeking shares of the considerable amounts of donor funding available in the early 2000s for arsenic-related activities. Many of the NGOs involved in the early BOTs may have misunderstood the difference between typical donor-funded arsenic mitigation work and the commercial intention behind the BOTs. Whatever their understanding, most of these NGOs demonstrated a more philanthropic approach to their operations than a commercial one. They focused primarily on providing a community service, rather than recovering their capital investment. This mind-set was reflected in the fact that monthly O\&M estimates by the scheme managers covered only routine costs, and did not include reserves for replacements and repairs, much less capital investment.

Projects. The projects also tended to be unattractive to entrepreneurs or businesses because of the way in which subsidy support was structured. Sponsors were required to pre-finance $90 \%$ of the project capital costs and collect the other $10 \%$ from communities. Of this amount, $50 \%$ would eventually be reimbursed, based certified achievement of construction milestones. The project's planned credit facility, which was intended to help secure financing for the entrepreneurs, was never established. Moreover, sponsors struggled to get 
households to make good on their commitment to contribute $10 \%$ of the scheme capital costs. Even when it was paid, the household share was almost never contributed upfront, adding to the financing pressure affecting sponsors.

Customers. Instead of the required 12 hours, services across the operating schemes were never extended for more than about six hours per day. This reduction in service was done to cut back on costs, in line with lower revenue collections. The tariffs charged for water services seemed affordable as a percentage of average income, but not enough households were connecting to the systems so total scheme revenues typically could not reach costrecovery levels. When customers did connect, they often lobbied successfully to have tariffs lowered from originally agreed rates. By the end of the project there was still no compelling evidence to confirm expectations regarding the willingness and ability of rural households to cover O\&M costs of the schemes, much less meet a significant share of capital costs.

$\underline{\text { Regulation. }}$. There was no government regulator for rural piped water supply and no formal mechanism for regulating BOT contract compliance except via the contracts themselves. However, this approach (known as "regulation by contract") works best when the contracting parties are clearly identified and contractual relationships straightforward. But in Bangladesh's rural water sector this is still not the case. By the early 2000s, the government was developing a policy to decentralize service delivery to the local level in order to ensure a more demand-driven, cost-effective, and sustainable approach in the water sector. The policy was formalized with the Union Parishad Act of 2009, which assigned responsibility for the provision and maintenance of rural water supplies to the Union Parishads (or UPs), the lowest level of elected rural local councils. If fully implemented, this policy would have established local level "public" partners for these piped water BOTs in rural areas. But even after the Act was passed, the national-level water agency - DPHE - remained the sole governmental entity with the technical capacity and authority in the rural water supply sector, because the UPs continued to lack the technical capacity to lead this sector. This meant that a national agency would continue to play the key role in designing, supervising, and contracting out rural water supply schemes until such time as the UPs were able to fully assume that function. In effect, this left a regulatory void within which the BOTs would have to operate. Community groups were expected to monitor BOT contract compliance, but they typically lacked the skills and resources to do this effectively and received little assistance from DPHE.

Technical support. BWSPP provided some capacity building and technical support to various project actors, but by the end of the project it was clear that more assistance was required than had been initially planned for under the project. Sponsors generally lacked the capacity to prepare their bids, design their projects, or do water quality assessments. In many cases it was apparent that they needed help understanding how to operate their schemes commercially. The PMU also lacked capacity in many of these areas. Local communities needed more help in dealing with sponsors and monitoring contracts. Higher level officials in DPHE were willing to explore innovative solutions, but DPHE was still far from a consensus view that the BOT model was more than one option among several under consideration. (One manifestation of this lack of commitment to the model was the absence of efforts by the government to play more of a role in providing the kind of support needed 
by rural private operators, local governments, and community organizations.) A stronger effort would be needed to help senior counterparts understand the model and its potential benefits, and play a more active role in attempts to roll it out.

Evaluation. As BWSPP concluded there were still aspects of BOT implementation that were not well understood. This was partly a result of the fact that by the time BWSPP was restructured in 2008, the project's monitoring and evaluation (M\&E) framework had not yet been developed. With the cutback in activity levels, plans for the framework were also scaled back. Normal project performance information was not collected by the system, and key design features associated with the rural piped water schemes were not evaluated. These features included issues such as the effectiveness of output-based aid approaches to subsidy payments, the project's focus on single water schemes rather than clusters, and how water quality could be more consistently monitored and regulated. 


\section{Subsequent Efforts to Scale Up and Evaluate the BOT Model}

\subsection{Bangladesh Rural Water Supply and Sanitation Project (BRWSSP)}

In 2012 DPHE and the World Bank collaborated once again to implement a follow-up to BWSPP (completed in 2010). The new effort was expected to build on the lessons learned from BWSSP and recent global experiences. The focus remained on rural areas and included three components including rural sanitation, non-piped water, and piped water schemes. The latter was focused on a refined version of the BOT model. The result was the Bangladesh Rural Water Supply and Sanitation Project (BRWSSP), a US\$75 million IDA credit for work to be undertaken over the 2012-2017 period.

Project summary. Under BRWSSP, piped water projects were initially to be implemented in approximately 125 areas where shallow tubewells were significantly affected by a combination of problems, including arsenic contamination, salinity, iron contamination, and a low water table. The plan was to address these problems by scaling up the BOT model that had been developed under BWSPP.

Each scheme was expected to achieve between 600-1,200 domestic connections. As long as the schemes proved to be technically and financially viable (using a minimum number of consumers as the threshold for viability) each would cover single or multiple villages depending on the density and number of households. Private sponsors (i.e., private entrepreneurs, NGOs, contractors, and cooperatives) would be selected competitively to construct and operate the schemes on behalf of the local government (UP), which would own the assets. The sponsors would receive OBA subsidies based on performance (measured via certified achievement of project milestones) for most of the project costs, but would still be responsible for significant levels of investment and long-term operation and maintenance of the facilities, all of which would have to be recovered from revenues.

In various ways, the BRWSSP approach incorporated modifications to the private sponsor model pioneered on earlier projects. Perhaps the biggest adjustment was a stronger focus on capacity building and technical support. This and other key differences included the following:

- Program management. Because it was now clear that DPHE did not have sufficient technical staff to adequately oversee its existing water supply programs, the department would receive a considerable amount of technical assistance to support its various project-related responsibilities. Part of this assistance would come in the form of a capacity building and training program. DPHE would also engage a private engineering consultancy firm to assist with various aspects of managing the selection and development of rural piped water schemes. The procurement of private sponsors was strengthened and simplified, with schemes batched into clusters of multiple villages in an effort to achieve economies of scale on the part of the sponsors, and reduce the number of procurement actions needed by the project.

- Sponsors. Tougher bidding requirements were adopted in order to increase the involvement of commercially-oriented enterprises and entrepreneurs as private sponsors, rather than NGOs. Prospective private sponsors would also receive training 
prior to bid submission so that they could comply fully with tougher submission requirements designed to make sure that sponsors were competent and commercially oriented.

- Projects. Due to a perceived shortage of sponsor technical skills, resulting in past problems with poorly designed, non-viable projects, it was decided that sponsors would no longer handle some key project selection and preparation tasks. DPHE, with support from their engineering consultancy firm, would now be responsible for feasibility studies and for the design and supervision of construction, as well as for scheme site selection. This meant in effect a partial abandonment of the classic BOT model that depended on sponsor involvement in design and construction to help facilitate operational efficiencies and sustainability during implementation. But improved site selection and scheme design were seen as acceptable trade-offs for diluting the BOT concept in this way. To make the schemes more attractive to private sponsors, the subsidy level per scheme was increased to 70\% from BWSPP's original level of $50 \%$. Although still output-based, the subsidies were mostly to be provided on achievement of construction milestones rather than service delivery ones, so sponsors would be reimbursed for capital investment earlier in the process than had been the case on earlier projects. Finally, in recognition of the difficulty in connecting households to these systems, the project was designed to allow sponsors full subsidy payment disbursements for achieving $70 \%$ of system connections rather than $100 \%$ as in BWSPP.

- Customers. The project continued to depend on the assumption that potential customers were willing and able to pay for services, as long as the schemes met expectations regarding quality and service levels. By more carefully designing and siting schemes, and implementing a more rigorous sponsor selection process, it was assumed that service quality and reliability would be higher and as a consequence customers would connect and pay their bills. By ensuring that the schemes installed metered connections, the sponsors could more accurately measure usage and allow customers to manage their own demand.

- Regulation. As asset owners, and in the absence of a formal regulator of rural water supply services, UPs were now expected to perform various regulatory functions. A technical assistance component introduced into the project would therefore (i) develop an institutional and regulatory framework to cover private sector participation in rural water supply, (ii) support increased delegation of responsibility to the UPs so that they could carry out their regulatory responsibilities, and (iii) facilitate the benchmarking of scheme operations to introduce accountability.

- Technical Support. As noted above, technical support to DPHE's PMU was to be significantly upgraded in order to capacitate DPHE, but also to ensure that DPHE could provide technical support to other actors in the process. To monitor service capacity and quality, the UPs would receive technical support from DPHE and its consultants. 
- Evaluation. The project's M\&E system was designed in specific detail, including plans to monitor sponsors' service and performance through annual audits and community surveys. The surveys would be conducted by external evaluators to obtain information about the performance, progress, outcomes, and impacts of project activities, including the piped schemes. Financial audits would confirm sponsor compliance with the terms of the service agreements. Annual or semi-annual benchmarking would be done to compare performance across sponsors. (Notably, the previous BWSPP project had conducted only one performance audit, which took place when the project ended.)

Results. The February 2015 Mid-Term Review showed that, as with the forerunner projects, BRWSSP had also encountered significant problems. After 34 months (just over half of the project period) only $7.4 \%$ of the funding had been disbursed. Of the 125 targeted BOT contracts, none had been completed. Eight schemes had been awarded and of those, only one - developed with grant support prior to the project - was $70 \%$ complete. With the exception of the latter, the Mid-Term Review estimated that no schemes would be completed before the end of 2016 - roughly six months before the project's planned closing date.

As a consequence of this lack of progress, the project was restructured to reduce the targeted number of schemes from 125 to 35, and the beneficiaries of piped schemes from 550,000 to 154,000. At least 90 schemes would have to be cancelled. DPHE estimated that 75 of these had already been discussed with and approved by local communities. In addition, the IDA allocation for the piped water component was reduced by US\$20 million.

While civil/political unrest in the country was partially responsible for the implementation delays, project-specific problems were also identified:

- $\quad$ Program management. Several stumbling blocks held up implementation of the plan to strengthen the DPHE and its PMU, including the following:

- Slow departmental decision making prior to sponsor recruitment meant that it took roughly two years to contract and mobilize DPHE's key technical assistance support team that was supposed to build internal capacity and carry out crucial project preparation activities.

- Once the technical assistance support team started to prepare pre-feasibility and feasibility studies they realized that the process was more complicated and time-consuming than anticipated. In addition, there were still problems with site selection and scheme design, which tended to compromise project sustainability. In some cases, needed treatment plants were left out of scheme designs to reduce capital and operating costs.

- Part of the extra time required for scheme preparation was due to difficulties experienced in "batching" schemes into village clusters. The batching, or packaging of multiple schemes, was supposed to make procurement easier and attract bidders with economies of scale. But batching was not allowed by the PMU. "Socio-political reasons" were cited, presumably meaning that the PMU did not want to give the impression that they were favouring certain 
regions over others. Whatever the reason, the inability to package multiple schemes for development complicated the due diligence carried out by the technical assistance teams and increased project preparation costs.

- Sponsors. Prospective sponsors continued to be unenthusiastic about project offerings, with many of the schemes failing to attract bidders. The PMU seems not to have done as much as expected in terms of market sounding or in promoting the schemes once target areas were selected, much less encouraging the participation of more technical and commercial bidders. Taking away sponsor responsibilities for decisions on scheme location and design may have improved the technical viability of the schemes, but may also have made them less attractive to bidders and probably increased the involvement of sponsors who were less knowledgeable about, and well known to, local communities. Sponsors who actually bid for schemes tended not to be from the class of larger commercial enterprises or the smaller, competent private entrepreneurs that the project was hoping to attract. The Mid-Term Review therefore recommended that pre-bid market surveys be conducted in each district to determine if there was enough interest among potential private sponsors to warrant a bid process. In other words, it was no longer assumed that all the schemes identified and developed by the PMU would automatically attract private sector interest.

- Projects. DPHE suggested in their input to the Mid-Term Review that the projects were not particularly commercial. This was due to the need for a $20 \%$ equity stake and the challenges associated with recouping this investment over the 12-year project period. DPHE thus requested that the OBA grant contribution be increased to $90 \%$ per project, which would have been more consistent with prevailing government policy and similar to the subsidy levels of the RDA projects. In essence, DPHE believed that the additional subsidy would make it easier to attract operators. DPHE also noted that the cost recovery potential of the schemes was further undermined by the need for them to pay for electricity at commercial rates, which were three times the level of irrigation rates. As electricity costs could be as much as $60 \%$ of total scheme operation costs, particularly if water treatment was involved, these higher rates were particularly damaging to the commercial viability of the schemes. The Mid-Term Review however did not change the cost-sharing structures of the schemes because bidding for 29 schemes had already started.

- Customers. With no schemes in operation at the time of the Mid-Term Review, it was impossible to judge customer willingness or ability to pay for water distributed by the schemes. However, based on all of the attempts to roll out the BOT model to date, it was becoming clear that even when communities agreed to the $10 \%$ equity contribution they were expected to make, that amount was almost never fully paid up front. While the experience in BRWSSP may improve as implementation continues, it appears that community contributions in the range of $5 \%$ may be more achievable.

- Regulation. The work on the regulatory and institutional framework had not yet started by the time of the Mid-Term Review and it was subsequently cancelled. (By the time 
of the MTR, the Asian Development Bank was supporting a policy reform activity covering the entire water sector in Bangladesh.)

- Technical support. During the first half of the project, the DPHE/PMU had not provided either the support or the regulatory oversight needed for the sustainable rollout of the BOTs. And because most of the training and capacity building for DPHE's PMU had not started by the time of the Mid-Term Review, $44 \%$ of this funding was subsequently cancelled, essentially guaranteeing a continuation of DPHE underperformance in this regard.

- Evaluation. With none of the schemes likely to be in operation before the end of 2016, the plans for financial audits, community surveys, and sponsor performance benchmarking were also cancelled.

\subsection{Reviewing the BOT model in Bangladesh: BWSPP Monitoring Report}

Because in 2005 BWSSP had been the first project to attempt a scale-up of the BOT model, WSP eventually initiated a monitoring program to assess progress of the 21 schemes set up by the project (13 of which had actually been developed under the earlier project, BAMWSP). In January 2015, WSP issued a monitoring report on the 21 BWSPP private sponsor schemes. ${ }^{3}$ All 21 schemes were under construction or in operation when the BWSPP project ended in 2010. But at that stage the majority of the schemes had not yet established a substantial track record. In addition, BWSPP's own M\&E system had never really started functioning. This meant that when planning for a renewed scale-up of the model under BRWSSP was initiated in 2012, there was limited knowledge about the actual performance of these schemes.

Accordingly, the 2015 WSP monitoring report represents one of the first comprehensive, published accounts of performance by these early BOTs. The report drew the following conclusions:

- $\quad$ Sustainability. Six of the 21 schemes were not operating for various reasons including equipment breakdowns and theft, iron contamination (in cases where no treatment unit had been installed), and non-payment of water bills by users. Of the six, three schemes had never started operation because of technical design problems.

- Management quality. Of the 15 operational schemes, the WSP report concluded that four were poorly managed.

- One scheme lost its treatment plant because of flood damage, but continued to sell untreated water to community customers, who in turn did not pay bills regularly due to the poor quality of service.

- A second scheme also had water quality problems. In addition, weak system pressure meant that more distant households often did not receive water.

\footnotetext{
${ }^{3}$ Two earlier reviews had been conducted, but the reports had not been formally issued.
} 
- A third scheme similarly had water quality problems and many households had started using their own tubewell water or water treated and sold by local venders.

- A fourth scheme had pipeline design problems - many users could not access water because of poor system pressure. Tariff collection was also poorly managed. After a dispute over tariffs with the local CBO water committee, the sponsor abandoned the scheme, leaving it under the management of the local government (the UP), which struggled to keep the system operating.

- Service levels. Supply hours typically ranged from three to six hours per day rather than the original target of 12 hours. This was because connection coverage of most schemes was limited to $50 \%-60 \%$, resulting in lower than anticipated demand and lower than expected revenues. Many potential customers expressed the view that because so much grant funding had supported the capital costs of the schemes, grants should also pay for household connections. Others were unhappy with the water quality and poor service standards.

- Network expansion. Connections declined in eight of the 15 functional schemes, mainly because customers either voluntarily disconnected due to inferior services (pressure failures in the supply lines or poor water quality), or were disconnected for non-payment of water bills (again, frequently due to dissatisfaction over weak water pressure or poor water quality). The WSP report established that no marketing or motivational programs had been undertaken to increase household connections by sponsors in any of these 15 schemes. Some of the sponsors attempted to access SME funding from commercial banks in order to finance system expansion, but found that local banks did not recognize small water operators as acceptable borrowers.

- Metering. While a number of household meters had been installed when the schemes were first constructed, most of them had stopped working or had been stolen in the years since. Metered bills had never been produced by any scheme. None of the sponsors had ever attempted to install new household meters to manage demand and increase income.

- Capital investment. No additional capital investments for system expansion or installation of additional facilities were ever made by any sponsor. Only three schemes maintained funds for major repairs or equipment replacement. Most sponsors lacked the technical capacity to rehabilitate or repair their own schemes, and generally were reluctant to make any further investments for repairs or to meet rehabilitation costs. Typically this unwillingness to invest additional funds was a contributory factor in the closing of those schemes that were no longer operational.

- Tariff rates and collections. As a consequence of increased operating costs (including electricity charges that were much higher than anticipated), tariffs increased for almost all of the schemes. Electricity charges typically represented $40-50 \%$ of total operational expenses, and even more if treatment plants had been added to the schemes. But none of the tariff increases were sufficient to meet capital investment 
requirements. Substandard service and poor water quality were cited as the main reasons for low collection rates. As a result the average collection rate across the operational schemes was unpredictable, with the FY 2012-13 rates at 84.3\%, jumping to $92.1 \%$ the following year.

- Profitability. Of the 15 functioning schemes, seven were operating at a loss, mainly because of low tariffs, poor collections, high electricity costs, and/or high water treatment costs. The average return on sponsor equity was only $2.75 \%$. WSP projected that only four schemes would be able to recover their original $30 \%$ sponsor investments over the 18-year contract period. But the report noted that the NGO sponsors operating most of these operational schemes were not doing so with commercial intentions.

- Other commitments. As per the BOT agreements, the sponsors were supposed to maintain proper accounting systems, including separate depreciation accounts, but none of the schemes were found to be in compliance with these agreements. DPHE had not conducted any of the agreed-on performance or financial audits of the scheme accounts. Only two of the 15 schemes had met their commitments to regularly test water quality. 


\section{The International Experience}

Across the developing world the private sector plays less of a role in water distribution than in other infrastructure sectors. This is generally because the water sector is considered less commercial than sectors such as transport, power, or ICT. Everyone needs access to water, but not everyone is willing or able to pay the full costs associated with water provision. In industrialized countries, full cost recovery from user fees has rarely been achieved for water provision (Foster and Yepes, 2006). And of course it is even less common in developing countries. So some level of public funding in the sector is considered essential. All of this is particularly true for water provision in rural areas, where low population densities and lower than average incomes make water networks difficult and even more expensive to build and maintain.

This section reviews a series of international research studies in an attempt to determine if there is any compelling evidence to suggest that modestly subsidized BOT contracts for rural piped water delivery can solve the problems associated with community management models, and do so in a sustainable, scaled up fashion.

\subsection{Kleemeier (2010)}

This was a desk-top study which reviewed 24 piped water projects, about half in Africa, and examined the experience of private water supply management in very small rural settlements. The review found that the projects often had problems finding competent private operators, and frequently could not generate sufficient revenues even after a private operator had become involved. In addition, governments and their development partners failed to provide professional support to local communities to enable them to interact with and regulate these private operators. Accordingly, a flaw in the design of these projects was the assumption that rural private operator initiatives could make competent government institutions unnecessary. Instead it was clear that government would need to play an ongoing role in the regulation, training, and professional support required by these schemes if they were to have a chance of succeeding.

However Kleemeier found that evidence was lacking on the financial sustainability of privately managed rural piped water schemes. Record-keeping on these projects was typically not adequate enough to support that kind of analysis. Evaluations were not carried out to collect and analyze data, and the studies that were done were not widely disseminated. While Kleemeier found cases of profitable BOT contracts in Burkina Faso and Paraguay, and both community and profitable private management schemes in Niger and Senegal, she concluded that even if the private operator approach appeared promising, the sustainability of the model was "not yet proven" (28).

\section{$6.2 \quad$ Foster (2012)}

Most of Kleemeier's findings were supported several years later in a second desk-top study by Foster, who established that over a quarter of rural piped schemes in Benin, Burkina Faso, Mali, Niger, Rwanda, and Senegal were privately operated. But Foster's review 
demonstrated that only a few isolated cases existed of private operators who invested their own money in schemes with the expectation of recouping full capital costs via user fees.

While he saw potential value in using BOT contracts to make possible the sustainable operation of rural water facilities, he noted that some kind of substantial subsidy would be essential to attract private involvement. He also agreed with Kleemeier that even if a vibrant rural water market could be established in a country, there would still be a need for competent government institutions to be involved in monitoring and regulating these projects, setting tariffs, managing contracts, and administering subsidies.

Finally, Foster concluded that little real evidence existed regarding the financial or technical performance of private operators, and he questioned "the viability of rural water businesses" (4).

\subsection{Sy and Warner (2014)}

In their 2014 study, Sy and Warner reviewed data and reports from three countries: Bangladesh, Benin, and Cambodia, and arrived at conclusions about the potential opportunities for domestic investments in water and sanitation in poor countries. The authors found that by 2025, about 20 million people in the three countries would need to access water from rural piped water schemes, i.e., ten times the current number. But the authors also found a mix of commercial and policy factors which would constrain the expansion of private schemes, including the following:

- Weak demand. Demand for water by poor households is currently not high enough for private operators to expand their system capacity, or even make full use of existing capacity. According to international health guidelines, poor households in these countries should be consuming more water, but because of tariffs and connection fees that they perceive to be high they are discouraged from doing so, especially given the quality of water being sold when compared to alternatives (e.g., rainwater, wells, springs, and boreholes). If operators can supply water that seems to be of good quality, it may help to increase the demand for piped water.

- Lack of viable business models. For privately managed schemes to be viable they must achieve 'size' economies of scale, with levels of sales and prices that are adequate to cover all of the system's costs. But governments and development partners have struggled to find business models that can achieve this kind of scale.

- Investment philosophies. In Bangladesh and Benin, where system designs are determined in a top-down fashion by the governments and their development partners, most of the investments that private operators were supposed to make were expected to cover repairs or maintenance. However, many firms are not profitable, and sponsors are reluctant to invest in the systems that they are operating. This is apparently due to doubts about the cost-recovery potential of their businesses. In Cambodia, most enterprises were planning investments in network and water production expansion, with half of them contemplating investments in new schemes. Their biggest concern however, was access to finance. In all three countries, firms 
interviewed by the authors said they believed that water was too expensive for poor people and that few incentives existed to increase access by the poor.

- Unsupportive policies and institutions. Government policies in all three countries limit access to investment in the water sector. In Bangladesh, tariff levels are not high enough to allow cost recovery, much less ensure a return on investment. Investment is therefore dependent on access to government or donor financing. In Benin, government design of overly-large systems has been a barrier to system expansion. In Cambodia the legal framework for semi-urban water supply may be limiting the types of investments that firms are willing to make.

Sy and Warner's study concludes with recommendations for action mostly by governments and development partners in three key areas: (i) stimulating the demand for network services by the poor; (ii) improving business viability and business models by removing policy and other impediments to efficient behavior by private firms; and (iii) improving the investment climate and the incentives to invest in challenging markets.

\subsection{Research on Community Management}

In addition to the studies referred to above, there is a vast research literature on community management of rural water schemes of all kinds. These schemes constitute the dominant service delivery model for water services in rural areas. The most relevant theme emerging from the literature (pertinent to this discussion on BOT service delivery models) is the increasing realization that the community management model has reached the limits of what can realistically be achieved through informality and voluntarism. This is one of the messages of a recent special issue of the journal, Water Alternatives (October 2013), which focused on new trends in rural water supply. The guest editors noted that behind the apparent success of the model in constructing assets and achieving first-time access to water supply is a combination of growing challenges: poor performance of service providers, high rates of sustained system failure, and very low levels of service. The editors and other contributors argue that the main actions needed to shift community management away from the limitations of its traditional model are already becoming apparent. The first and most significant action involves making the model more professional, with some modest forms of sector regulation to hold operators accountable for performance and provide capacity building for communities to instill good business practices. Thus they contend that, "in some cases, professionalization may go as far as fully outsourcing some or most service provision to private operators" (336). Above all, they make the case that professionalization will require external technical support, and that structured support programs have proven to be more effective than ad hoc support, especially when it comes to improving O\&M and administrative functions.

\subsection{Other Research}

Finally, various other studies suggest that the potential for private participation in the water sector, even in urban settings, has often been over-estimated when it comes to profits and investment. A comprehensive review of this literature is beyond the scope of this paper, but several research papers are worth considering: 
- The first is a study by Sirtaine, et al. (2004), which used a sample of both brownfield and greenfield projects and included water projects along with those in other sectors, to assess the profitability of PPP projects in Latin America during the late 1990s. The study found that on average, projects demonstrated profitability only after about 10 years of operation. Prior to that point, project shareholders earned negative returns on their investments, even when adding in things like management fees, estimated accumulated capital gains, and potential investment markups. But this same study also found that $40 \%$ of the concessions in the sample did not have the potential to ever become profitable, with water concessions being the type of project that was least attractive to private operators.

- A second study, by Gassner, et al. (2009), looked at whether privately operated water and electricity utilities outperformed those run by governments. The study used a data set of more than 1,200 utilities in 71 developing countries. For the water projects, the study found significant gains in performance and labor productivity, but no evidence of increased investment generated by private participation.

- A third study, by Marin (2009), undertook a global review of public-private partnerships for urban water utilities in developing countries. The study focused on 65 large urban water PPPs in operation for at least five years. Marin concluded that the principal benefit of these projects was operational efficiency and service quality rather than the ability to supply private sector finance. He acknowledged that private investment was the main attraction of PPPs in the water sector in the 1990s, but added that "experience has shown that this was largely the wrong focus" (7). He noted that in the case of poor households, subsidies are often required for consumption as well as to increase access (135).

- Finally, Estache and Philippe (2012) reviewed research literature since 2007 on the impact of private participation in infrastructure in developing countries. They noted that water deals were the most difficult to do among infrastructure sectors, and that a resurgence of interest in management contracts in the sector "can be seen as an explicit recognition that this sector cannot be expanded without public financing" (3). Evidence of increased efficiency in water projects due to private sector participation "is at best mixed in all developing regions," because of the importance of the legal/regulatory environment in which such projects are implemented (5).

These four research studies focused on large, mostly urban water PPPs that were not set up initially with large amounts of subsidy funding. So at first glance they may seem irrelevant to a discussion of highly subsidized, rural water projects. But the studies demonstrate that neither the large projects that stimulated interest in water PPPs in the 1990s, nor the smaller rural projects, were as profitable as assumed at the time. These projects also did not generate the kind of private investment that was frequently cited as their principal benefit. If the larger urban PPPs could not meet these expectations, it is not so surprising that smaller rural projects would have difficulties consistently demonstrating profitability and increased private investment, even with partial capital subsidies. 


\subsection{Lessons from the International Literature Review}

This review considers only a few of the important studies that have looked at private participation in rural water supply in poor countries. Nevertheless these studies do present some common themes which are summarized below:

1. Water schemes involving private operation continue to show promise but particularly when there are critical elements such as strong private partners, capacitated local partners, and clear regulatory regimes in place. In many instances, interest in private sector participation has grown as the shortcomings of traditional community management schemes have become increasingly evident. But the rural water sector is rapidly moving beyond a debate about the merits of classic PPP operations versus traditional community management schemes. Many kinds of hybrid schemes are appearing, particularly in countries like Rwanda, Senegal, and Benin, involving operations owned and supervised by community groups, but operated by private contractors. Yet this model is in its infancy and more experience and analysis is required before determining that the hybrid model can deliver at scale.

2. It is still assumed that schemes involving private operation tend to perform better than community operated schemes in terms of system maintenance, revenue management, water service delivery, etc. While this may be accurate, there are relatively few private operator schemes that have been successfully set up and sustained. And the results ultimately need to be reviewed in comparison to public sector delivery models which varied widely, not only between regions and countries, but also by sub-national service provides. Further analysis and research is needed to fully assess the impact of private operators, particularly when compared to local public service providers.

3. As noted above, countries like Senegal and Benin have had some success with private operator models in rural areas and those efforts are now moving to scale. Nevertheless, there has not yet been a model that has successfully scaled up private operator models in hundreds of schemes simultaneously.

4. It is now widely accepted that private operators can only deliver rural piped water services with some form of capital subsidy. The idea that user fees can cover O\&M expenses, while still commonly accepted, is less established in many developing countries as policy makers hesitate to establish tariffs which cover the full maintenance and rehabilitation costs. Whether the policies support water as a human right or an economic commodity, either the public sector, consumers, or some combination of the two must find models to cover O\&M costs.

5. Access to affordable finance by small operators seems to be essential for the BOT model to work, but beyond a few isolated success stories, such access is still a challenge in many countries. The combination of short tenors and high interest rates has inhibited the access to capital to support water projects.

6. Most researchers argue that private participation in rural piped water supply must be augmented by capable government officials and institutions. For private participation to be sustainable, governments must maintain some functions to support private sector 
involvement. Such functions include things like setting appropriate policies, applying regulatory frameworks including tariff setting, developing sector strategies, providing support for community engagement programs, and supplying technical support to small scale private operators. 


\section{Conclusions}

This review leads to three important questions. The first is what do we know now as a result of the experiences in utilizing the BOT model for the provision of safe water to large numbers of households in rural areas of Bangladesh? In other words, what are the important lessons learned from these programs? The second question is what non-BOT options might be considered in the future? Finally, the third question is what additional analysis is needed to make informed decisions to address rural water supply constraints in Bangladesh? These three questions are addressed in the following sections.

\subsection{Lessons Learned About Implementing the BOT Model}

The results of the GOB-World Bank collaboration to scale up the use BOT models for water provision in rural areas in order to deal with widespread arsenic contamination of ground water has been disappointing. To better understand this it might be helpful to identify what seem to be the essential program elements necessary to achieve such a scale up. Box 4 presents a stylized description of these elements, condensing earlier lists of such elements (e.g., in Box 3) from seven to four, and highlighting their interdependence. They are interdependent in the sense that each leads to the next: viable, commercial BOTs depend on the ability of the program management entity to design such projects and indentify competent private operators. Private operators are attracted to the projects only if they are well designed and clearly viable, with transparent subsidies and tariff levels set to adequately generate profits. Customer are willing to pay for water and make the projects viable only if operators are supplying a product that is convenient and of desirable quality. Unfortunately, as summarized in the following sections, few of these program elements were achieved, and the chain of interdependent results or outputs was never linked together. 


\begin{tabular}{|c|c|c|}
\hline \multicolumn{3}{|c|}{ Box 4: Making the BOTs Work -- Essential Program Elements } \\
\hline Program Elements & Essential Characteristics & Expected Outputs/Results \\
\hline \multirow{4}{*}{$\begin{array}{c}\text { 1. Program } \\
\text { Management Entity }\end{array}$} & $\begin{array}{l}\text { A motivated, high capacity, team } \\
\text { responsive to deadlines }\end{array}$ & \multirow{4}{*}{$\begin{array}{l}\text { Large numbers of commercially } \\
\text { viable projects designed and bid out }\end{array}$} \\
\hline & $\begin{array}{l}\text { Willing/able to identify and procure } \\
\text { competent operators }\end{array}$ & \\
\hline & $\begin{array}{l}\text { Willing/able to monitor contract } \\
\text { compliance }\end{array}$ & \\
\hline & $\begin{array}{l}\text { Willing/able to provide on-going } \\
\text { technical support }\end{array}$ & \\
\hline \multirow[t]{4}{*}{ 2. BOT Projects } & $\begin{array}{l}\text { Manageable size \& technology given } \\
\text { skills and financing ability of operators }\end{array}$ & \multirow{4}{*}{$\begin{array}{c}\text { Large numbers of projects that are } \\
\text { attractive to commercial operators } \\
\text { and customers }\end{array}$} \\
\hline & $\begin{array}{l}\text { Costs are accurately estimated and } \\
\text { controllable }\end{array}$ & \\
\hline & $\begin{array}{l}\text { Revenues are sufficiently subsidized } \\
\text { to achieve profitability }\end{array}$ & \\
\hline & $\begin{array}{l}\text { Tariff setting process ensures stable, } \\
\text { cost-reflective pricing }\end{array}$ & \\
\hline \multirow[t]{4}{*}{ 3. Private operators } & $\begin{array}{l}\text { Willing/able to manage commercial } \\
\text { projects }\end{array}$ & \multirow{4}{*}{$\begin{array}{c}\text { Large numbers of sustainable, } \\
\text { commercial water delivery } \\
\text { businesses }\end{array}$} \\
\hline & $\begin{array}{l}\text { Willing/able to monitor/ maintain/ } \\
\text { rehabilitate assets }\end{array}$ & \\
\hline & $\begin{array}{l}\text { Willing/able to interact effectively } \\
\text { with customers }\end{array}$ & \\
\hline & $\begin{array}{l}\text { Access to finance needed for initial } \\
\text { investments and maintenance }\end{array}$ & \\
\hline \multirow[t]{4}{*}{ 4. Customers } & $\begin{array}{l}\text { Desire water that is safe as well as } \\
\text { convenient and good quality }\end{array}$ & \multirow{4}{*}{$\begin{array}{l}\text { Large numbers of rural households } \\
\text { accessing safe drinking water }\end{array}$} \\
\hline & $\begin{array}{l}\text { Little or no access to cheaper } \\
\text { alternative water sources }\end{array}$ & \\
\hline & $\begin{array}{l}\text { Willing/able to pay tariffs at O\&M } \\
\text { levels }\end{array}$ & \\
\hline & $\begin{array}{l}\text { Willing/able to pay a share of capital } \\
\text { costs as project begins }\end{array}$ & \\
\hline
\end{tabular}

Program management. A competent program management entity is the foundation for a program of this kind due to the critical functions it must carry out. Its most important functions are to design viable BOTs and find competent private operators. With any kind of PPP it is essential to ensure that the private partner is capable of fulfilling its project obligations over the life of the contract because the public partner faces a variety of contingent liabilities that can materialize if the deal collapses. The need to thoroughly evaluate private partners was recognized in the design of the different Bank-funded BOT support projects.

But the overall management of the BOT roll-out processes was never robust enough to handle the hundreds of schemes planned for development. The GOB and the World Bank struggled 
to find an effective delivery model for setting up and staffing a project PMU to manage the complicated process of designing or evaluating schemes, and procuring sponsors for projects. The risks associated with weak program management were well understood in the early 2000s, but solutions to the problem proved to be elusive.

The absence of a strong program management entity had knock-on effects across the program. All of the key actors in the BOT roll-out needed technical support and capacity building at the same time. DPHE was required to play a key role in providing this support to sponsors and the UPs, but it too had strained capabilities. The delays experienced in building DPHE's capacity added to this complexity. How and where to start such a capacity building process, how to sequence it, and how to manage it, are all challenges that undermined the roll-out of BOTs.

Going forward with a BOT program, the capacity of a government implementing agency would have to be strengthened considerably before the project tries to start rolling out BOT schemes (rather than as part of the roll-out). The search for local institutional partners to host and staff a PMU should also continue, perhaps considering entities such as RDA. ${ }^{4}$

Projects. Several characteristics of the schemes made them appear to be risky and unattractive to potential sponsors. For example, the BOT schemes were larger, more complex, and more expensive than RDA schemes, which was probably a reason why the latter program was so much more successful in attracting operators. ${ }^{5}$ The costs associated with the delivery of water were also higher than expected, with schemes being charged for electricity at commercial rates (rather than at residential or irrigation rates) and relatively expensive treatment facilities needed more frequently to deal with the arsenic issue. The need to pre-finance the capital costs of the schemes may have made the prospect of taking them on seem even less prudent to sponsors. Finally, the full disbursement of subsidies proved difficult in cases where achievement of outputs was limited by other shortcomings of the schemes, such as the failure of communities to contribute their full $10 \%$ share of capital costs. Because subsidy payments were subject to taxes and VAT, sponsors automatically received $10 \%$ less than some of them expected.

The regulatory environment within which these BOT schemes had to operate also contributed to their lack of viability. Currently there is no regulator for rural water projects in Bangladesh, which means there are no authoritative service delivery standards or procedures for setting

\footnotetext{
${ }^{4}$ In the mid-2000s RDA and the World Bank apparently discussed collaboration on rural piped water projects. But for a number of reasons the relationship was not pursued. One problem at the time was that RDA is a research and training institute and not classified as an "implementing agency" of government. That particular problem was solved with the creation by RDA of the Centre for Irrigation and Water Management, which does qualify to implement projects. Another problem may have been the fact that RDA projects are multipurpose and depend on revenue from both irrigation activities as well as household use. This might create problems for development agencies that normally employ separate divisions to fund and manage these two kinds of activities.

5 The RDA schemes are roughly half the size of the BOT schemes, largely because they serve smaller user populations, and therefore use smaller overhead tanks and more limited piped distribution networks, and typically do not include treatment plants. This makes the $10 \%$ down payment less burdensome for sponsors. The fact that RDA fully constructs the schemes before handing them over the sponsors eliminates construction risks, and substantially reduces pre-financing risks. In addition, RDA provides technical support to the schemes as well as access to a micro-credit revolving fund, which helps sponsors promote water-related income generating/ SME activities in the scheme area.
} 
and raising tariffs. As a result, tariffs for many schemes were not ultimately set at the costrecovery levels called for by the BOT feasibility studies, and therefore revenues could not cover of O\&M costs. Under such conditions, tariff-setting became a matter of negotiation between sponsors and user groups. The effort to have UPs act as local regulators was largely unsuccessful because of capacity shortcomings. ADB is currently assisting with the development of a regulatory framework for rural water supply so some of these problems may diminish in the future.

Finally, both Kleemeier (2010) and the BWSPP ICR (World Bank, 2011a) raised concerns about the effectiveness of output-based aid in respect of supporting BOT project outcomes. In some instances, OBA subsidy programs can involve high transaction costs and can be complex, with multiple payments contingent on the certified achievement of multiple outputs. This cost and complexity, when combined with the need for service providers to pre-finance investments (for which OBA reimburses them only after output achievement) sometimes makes OBA schemes less than effective at attracting private investment. Local commercial lenders typically refuse to treat OBA subsidies as collateral or any other kind of security for loans (Kumar, et al., 2010). ${ }^{6}$

Going forward with BOTs, further analysis would be helpful to better understand how OBAstyle subsidies impact small BOT projects, how OBA compares with the subsidy approach used by RDA, and whether there other types of subsidies, such as up-front capital grants (e.g., "viability gap funding"), which might be more productive. It also seems worth examining whether capital subsidies should be higher and whether some kind of operating subsidy is needed to facilitate the sustainability of schemes and attract competent sponsors. Finally a solution needs to be found to the high electricity rates charged to the BOT schemes. With government backing in light of the arsenic crisis, it is difficult to believe that these schemes could not be charged at residential or irrigation levels, rather than full commercial rates.

Private Operators. To date, the professional and entrepreneurial capacity of most of the selected private sponsors has not meet expectations. Individual entrepreneurs and private commercial enterprises have been far less attracted to the BOT schemes than NGOs, although this appears to be evolving in the latest round of sponsors under BRWSSP. NGOs have frequently agreed to act as sponsors, but have not able to apply a commercial approach to their schemes. Many have not had sufficient financial and technical expertise to do so. As a result a significant number of the BOT sponsors have not been particularly careful about covering costs, maintaining assets, or sustaining service quality. Poor management of the schemes has led to customer dissatisfaction, disconnections, and insufficient revenues, which in turn have led to further reduced service quality.

More traditional PPP private partners such as engineering firms or entrepreneurs have yet to demonstrate interest in these schemes although this appears to be evolving under BRWSSP where are number of joint ventures have prepared bids. In retrospect, it appears that competent, commercial sponsors either assessed these BOT projects as being incapable of generating profits or were unwilling to wait $12-15$ years to realize those profits. It also

\footnotetext{
${ }^{6}$ These kinds of problems have been cited in the past as reasons why OBA does not seem to have scaled-up as much as would be expected based on its various performance reviews (Trémolet, et al., 2009).
} 
appears that some of this has to do with the relatively high levels of pre-financing required under the schemes.

Going forward with BOTs, engagement is needed with potential private operators in order to better understand their interests and concerns related to managing water schemes. This means better market sounding, as well as greater effort to promote project opportunities among desirable kinds of private operators. Government implementing agencies must be convinced that professional private participation can contribute to more cost-effective service delivery and need to be motivated to help make such participation a reality.

Customers. Many prospective customers refused to connect to the networks, while existing customers were disconnected over time (either voluntarily or involuntarily). This was a complex and frustrating problem. An assessment of total family incomes demonstrated that most households could afford to pay for these water services. But their willingness to pay seems to have had the potential to sharply decrease as they weighed the costs involved against the quality of the water, the reliability and convenience of service, and the availability of alternative water sources. The 2003 willingness to pay study demonstrated that concern over arsenic contamination was not the main reason for preferring piped water schemes, and was not a deterrent that would keep households from accessing unsafe sources of water if the convenience and quality (meaning taste and appearance) of piped water were deemed unsatisfactory. In addition, the government and other development partners have continued to install fully subsidized tubewells across the country, so residents in BOT service areas frequently had other, cheaper options for safe water.

Going forward with BOTs, public awareness of arsenic contamination in rural areas needs to be improved although this needs to be linked to service level improvements (this is discussed in more detail in the next section). It is also worth noting that programs like this tend to be more successful using a demand-responsive approach, meaning that end-users have a say in system designs, project siting, service levels, etc. This tends to improve their sense of scheme ownership and willingness to pay for services. Because these BOT schemes involved significant community financial contributions, efforts were made early on to engage local communities in the schemes, conduct willingness to pay surveys, etc. The need to do this was clearly identified in project appraisal documents. But some of the early NGO operators now admit that surveys were not done thoroughly or at all. System design and site selection responsibilities were originally allocated to bidders in the hope that they would make an effort to engage with local communities about the projects. But those responsibilities were later taken away from bidders and handled by DPHE in a top-down fashion, in order to improve the overall technical sustainability of schemes. Unfortunately, because of the need to address the arsenic problem, simpler and less expensive service delivery alternatives like shallow wells and hand pumps could not be entertained. However it seems likely that this shift to more of a top-down approach probably weakened community ownership of the schemes. Ultimately the BOT programs were based on the expectation of community support in response to the provision of arsenic-free water. It is now clear that safe water was not enough by itself to guarantee community support. 


\subsection{Non-BOT Options Going Forward}

Should another attempt be made to scale up the BOT model for rural piped water provision in Bangladesh? Previous efforts were driven by the urgent need to deal with the health predicament the country faced as a consequence of groundwater arsenic contamination. Most of the non-piped water schemes supported by the World Bank in these projects did expand access to safe water and these efforts have not been evaluated as part of this review. However, in the case of BOT projects, the efforts to scale up the BOT model have been disappointing. In fact, efforts to scale up the use of the model were initiated before it was clear that the model had performed well in the early pilot projects like SIPP-1 and BAMWSP (Table 1).

Table 1: BOT Project Track Records as at Project Close

\begin{tabular}{|c|c|c|c|c|c|}
\hline WB-supported Projects & Dates & $\begin{array}{c}\text { Initial } \\
\text { Targets }\end{array}$ & $\begin{array}{c}\text { Revised } \\
\text { Targets } \\
\end{array}$ & $\begin{array}{c}\text { Results at } \\
\text { Project Close }\end{array}$ & Comments \\
\hline Designing and testing the model: & & & & & \\
\hline $\begin{array}{l}\text { Bangladesh Arsenic Mitigation } \\
\text { Water Supply Project (BAMWSP) }\end{array}$ & 1998-2006 & 13 BOTs & - & $\begin{array}{c}1 \text { under } \\
\text { construction; none } \\
\text { operational } \\
\end{array}$ & $\begin{array}{l}\text { The } 13 \text { schemes later included in } \\
\text { BWSPP's revised target of } 21\end{array}$ \\
\hline $\begin{array}{l}\text { Social Investment Program Project } \\
\text { (SIPP-I) }\end{array}$ & 2003-2011 & 6 BOTs & - & $\begin{array}{l}5 \text { under } \\
\text { construction; } \\
1 \text { operational }\end{array}$ & $\begin{array}{l}\text { By } 2014,1 \text { BOT cancelled; only } 2 \\
\text { covering operating costs }\end{array}$ \\
\hline \multicolumn{2}{|l|}{ The first attempt to scale up the model: } & & & & \\
\hline $\begin{array}{l}\text { 3. Bangladesh Water Supply Program } \\
\text { Project (BWSPP) }\end{array}$ & 2005-2009 & 300 BOTs & 21 BOTs & $\begin{array}{c}\text { Most still under } \\
\text { construction; } \\
\text { several operational }\end{array}$ & $\begin{array}{l}\text { By 2015, } 6 \text { BOTs cancelled; only } \\
4 \text { likely to recover investment }\end{array}$ \\
\hline \multicolumn{2}{|c|}{ The second attempt to scale up the model: } & & & & \\
\hline $\begin{array}{l}\text { Bangladesh Rural Water Supply \& } \\
\text { Sanitation Project (BRWSSP) }\end{array}$ & 2012-2017 & 125 BOTs & 35 BOTs & $\begin{array}{c}\text { At mid-term, } 8 \\
\text { under construction; } \\
\text { none operational }\end{array}$ & $\begin{array}{l}\text { At mid-term, cancellation of } 90 \\
\text { schemes already planned }\end{array}$ \\
\hline
\end{tabular}

Source: World Bank Project Documents

Other development partners active in Bangladesh remain unconvinced that the model is capable of being scaled up at this point in time. They continue to support more conventional models of water service delivery, including community management approaches. As a result, the government has been faced with conflicting recommendations from its development partners. For example, as the WBG's first attempt at scaling up the BOT model under BWSPP was concluding in 2009, the Asian Development Bank's Independent Evaluation Department concluded the following about the water sector in Bangladesh:

Support for reforms has not been coordinated well enough, and was sometimes misguided (support for private sector-based solutions in rural water supply, which in the context of Bangladesh are premature). (ADB, 2009, 45)

If alternative delivery models are to be explored, what kinds are available for providing safe water in Bangladesh's rural areas? The M\&E systems for the two large Bank-funded projects designed to scale up the model were never operationalised so data on the performance of the 
schemes is limited. And much of the information on the performance of other kinds of schemes in Bangladesh appears to be anecdotal and sometimes inconsistent. Nevertheless, some observations are possible regarding alternatives to the BOT model.

Program Management. Whatever service delivery model is adopted, some kind of program management entity must administer the roll-out of schemes. As mentioned above, this might be dealt with via more and earlier technical assistance for government agencies, or the use of non-governmental entities like RDA. In fact, abandoning the BOT model might improve the willingness of government officials to support the approach, especially if total subsidy levels could be increased to bring them in line with current government policy.

Projects \& Operators. Another option in rural areas could be less ambitious kinds of PPPs, or schemes that combine subsidized community ownership and supervision with outsourced private management. A variety of stakeholders have recommended capital subsidies of $90 \%$ (or higher) for rural piped water schemes, as well as operating subsidies. The introduction of such subsidies for BOT projects in Bangladesh would be a major shift in the long-standing BOT approach, but is perhaps unavoidable in light of the past performance of these schemes and the associated challenges of getting public sector delivery to scale. Stakeholders such as DPHE, RDA, BMDA, the Social Development Fund (SDF), and the HYSAWA Fund all advocate or use larger subsidies. Types of operator contracts that would be supported by such subsidies could include the following:

- Management contracts. Government could build schemes and contract them out to private managers who would operate and maintain the systems, but be paid directly by government instead of via user fees. ${ }^{7}$ However, private operators might be reluctant to take on the risks of operating schemes designed and built by government, so several variations of this approach, involving private design and construction, have been recommended in Bangladesh, including design-build-lease contracts and design-buildoperate contracts (Hydroconseil and DevCon, 2013). Lease or affermage contracts, like those used in several West African countries, might also be an option in Bangladesh. ${ }^{8}$ But management and lease contracts also have uneven track records in developing countries, which might put off prospective private sponsors. Even when contractors meet performance targets, they are often blamed for sector-wide problems over which they have little control. As a result, such contracts demonstrate high rates of renegotiation and premature termination.

- Clustering schemes. In order to achieve economies of scale, diversify operator risks, and possibly attract more professional sponsors like local engineering firms (or even international operators in partnerships or as sub-contractors with local firms), schemes could be clustered together to form much bigger projects for management contractors. Clustering would depend to some extent on the geographical proximity of schemes and

\footnotetext{
${ }^{7}$ Management contracts have been recommended as an alternative to BOT schemes by the Social Development Fund, which implemented six pilot BOT schemes with Bank support beginning in 2003 under the SIPP-1 project.

${ }^{8}$ In the most common form of affermage, the operator takes its fee from customer receipts, but also charges customers a surcharge covering additional asset investments. Unlike management contracts lease or affermage contracts leave demand risk with the operators so are somewhat more risky from a private sector point of view.
} 
the use of clustering would also have to be based on a thorough understanding of domestic and international operator interests and tolerances regarding rural water supply systems.

- RDA-style contracts. RDA has had some success in implementing its own version of PPP-type contracts, involving heavily subsidized schemes operated by local families or entrepreneurs on behalf of water user associations. RDA claims over 200 schemes in operation and relatively little difficulty in attracting operators (see Sect. 2.2 above). The model is far from perfect: (i) RDA admits that only about half of the existing schemes are reasonably well maintained, (ii) subsidy levels are high (90\%), and (iii) risks are low for private sponsor/operators (the subsidy is not performance-based). Many of the schemes seem capable of covering costs, but profit generation is not robust. Despite these challenges, the RDA approach has demonstrated modest success in Bangladesh, especially when compared with the water delivery performance of alternative models.

- Hybrid models. Recent research by groups like the International Water and Sanitation Centre (Moriarty, et al., 2013) suggests that the emerging service delivery model in this subsector, which is most responsive to user demands and government mandates and constraints, may lie somewhere between BOT-type approaches and traditional community management schemes. This emerging hybrid combines characteristic of both approaches. It results from the realization that the community management model is reaching the limits of what can be realistically achieved using an approach based on informality and voluntarism, and that sustainable achievement of desirable levels of service delivery do not always result from this approach. The hybrid involves a continuation of community management principles, but with a stronger degree of professionalism and external support to community owners of schemes. In many cases this means fully outsourcing most service provision tasks to private operators, with asset ownership and final decisions on service levels and tariffs remaining with communities or local government. In effect, private participation is carried out on the basis of management or service contracts. But as with those forms of private involvement, if costs are not estimated on a fully life-cycle basis, financing is not provided, and some kind of tariff-setting regulation is not in place, private operators may be blamed for service delivery shortcomings that are not fully under their control.

- Professionalization contracts. In rural areas perhaps the first step should focus on existing schemes rather than new ones, regardless of how they have been structured. Professionalization contracts have been developed in India for mid-sized urban utilities, but might be adaptable for smaller schemes in a country like Bangladesh, which have been developed by RDA, DPHE, donors, or MDBs. In India, these contracts involve private firms contracted to help municipal water utilities implement Standard Operating Procedures for each functional area of the utility, such as network management, commercial functions, administration and finance, and capital planning and management. The contractor would also advise on billing systems, asset management, leak detection, and maintenance. The contractor would then provide training and on-going management advice. Actual management control of the utility would not change hands. ${ }^{9}$ These are not

\footnotetext{
${ }^{9}$ See Ehrhardt, Mugabi, and Kingdom, 2015.
} 
PPP arrangements, so private contracts cannot be expected to cover any of these costs funding for these contracts, and for any needed capital investments, must be sought elsewhere.

Customers. Perhaps rural areas in Bangladesh should be left to an enhanced community management model that builds on existing efforts undertaken by the government and other development agencies, with more emphasis on professionalization of services, contracting out operations, and long-term sustainability. The management of rural piped water schemes using PPP-like approaches could be reserved for reasonably well capacitated local governments (UPs) in rural areas, like the 37 schemes developed by the HYSAWA Fund. ${ }^{10}$ Experience in Bangladesh suggests that private participation in infrastructure services might be much more sustainable in peri-urban environments due to higher population densities, better informed and more affluent customers, and more interested, competent small local businessmen acting as operators.

But whatever service delivery model is chosen, if households better understood the risks of drinking water contaminated with arsenic, and if dangerously contaminated boreholes were more frequently identified and shut down, the willingness to pay for piped delivery of safe water could be much more robust. But if anything, the public outcry over the arsenic threat seems to have diminished since the early 2000s, despite recent research showing that the problem may be larger and more dangerous than previously thought (Argos, et al., 2010). New awareness campaigns could generate multiple benefits if they were better designed and resourced than past efforts. But any such awareness campaign would only be effective if it was linked to some kind of comprehensive solution to the arsenic problem, including the provision of clean water. As a next step, there is a need for a better understanding of the social and economic costs of arsenic contamination, as well as the costs of effectively addressing it using different options.

\subsection{Two Longer-term Knowledge Objectives}

At least two additional set of issues need clarification in the Bangladesh context, regardless of which service delivery model is selected to deal with the arsenic problem. Ideally, efforts to clarify these issues would already have started. But in the haste to find solutions, not enough in depth analysis was undertaken to address these issues. These are multi-facet matters and resolving them will require significant resources as well as close collaboration between development agencies and the government.

The first issue involves gaining a better understanding of how water pricing is done across Bangladesh, and the extent to which subsidies are available to supplement user fees. There are apparently no standardized methods for pricing or subsidy provision. Water pricing does not appear to be linked to capital expenditures, O\&M requirements, or affordability. There is a lack of information and transparency regarding the size and extent of the subsidies available in the sector as well. Policies to regulate the water sector and review and adjust tariffs are under development, but implementation modalities and capacity support are still in the early stages of review. While many of these issues around water pricing and subsidies are sensitive,

\footnotetext{
${ }^{10}$ The Fund reports that after five years of operation, 25 of these schemes appear to be generating surpluses.
} 
further research, analysis, and capacity support for water pricing, subsidy provision, and assistance in implementing a regulatory regime, seem essential no matter what delivery model is ultimately selected. The unenthusiastic private sector reaction to the BOT models on offer was due in many cases to the lack of regulation that could maintain tariffs at cost-reflective levels and the many prominent examples of higher subsidies provided to other governmentsupported water schemes.

The second issue involves the need for a compelling recommendation regarding the most cost-effective model for the delivery of safe water in rural areas, which the government ultimately can support with limited outside assistance. Ultimately this analysis would identify a sustainable, affordable model to deliver clean water, at scale, in rural areas. More specifically, this involves comparing the total life-cycle costs and benefits of the BOT model with various other delivery models promoted in rural areas by the government and other development agencies, or with delivery models used in other countries (such as the hybrid schemes emerging in West Africa). The comparison of models and indeed the conceptualization of new approaches going forward needs to be done in terms of comparing the total, life-cycle costs of providing services at a defined level to a defined user population over time. Box 5 lists cost components, identified by Fonseca, et al. (2011), which offer a convenient framework for establishing total life-cycle cost profiles for different models.

\begin{tabular}{|c|c|}
\hline \multicolumn{2}{|c|}{ Box 5: Cost Components of Water Services } \\
\hline $\begin{array}{l}\text { Capital expenditure - } \\
\text { hardware and software } \\
(\mathrm{CapEx})\end{array}$ & $\begin{array}{l}\text { Expenditure on fixed assets such as physical infrastructure } \\
\text { (for initial construction or system extension), and the } \\
\text { accompanying 'software' such as capacity building. }\end{array}$ \\
\hline $\begin{array}{l}\text { Operating and minor } \\
\text { maintenance expenditure } \\
(\mathrm{OpEx})\end{array}$ & $\begin{array}{l}\text { Expenditure on labour and materials needed for routine } \\
\text { maintenance which is needed to keep systems running, but } \\
\text { does not include major repairs. }\end{array}$ \\
\hline $\begin{array}{l}\text { Capital maintenance } \\
\text { expenditure (CapManEx) }\end{array}$ & $\begin{array}{l}\text { Renewal, replacement and rehabilitation costs which go } \\
\text { beyond routine maintenance. }\end{array}$ \\
\hline $\begin{array}{l}\text { Expenditure on direct } \\
\text { support (ExpDS) }\end{array}$ & $\begin{array}{l}\text { Costs of ongoing support to users and local stakeholders, } \\
\text { for example on local government or district support staff. }\end{array}$ \\
\hline $\begin{array}{l}\text { Expenditure on indirect } \\
\text { support (ExpIDS) }\end{array}$ & $\begin{array}{l}\text { Costs of higher-level support, such as government } \\
\text { planning, policy-making and regulation. }\end{array}$ \\
\hline Cost of capital (CoC) & Costs of servicing capital such as repayment of loans \\
\hline $\begin{array}{l}\text { Cost of project preparation } \\
(\mathrm{CoP})\end{array}$ & $\begin{array}{l}\text { Costs of pre-feasibility and feasibility studies, } \\
\text { procurement, and contracting }\end{array}$ \\
\hline
\end{tabular}

The point of this analysis would be to determine the resources needed to make the schemes sustainable - and thereby facilitate a subsequent discussion of how to source adequate financing for these costs. Very careful attention needs to be paid to "capital maintenance expenditures" for the long term operation of these schemes. Both the BOT and community maintenance models assume that communities will cover O\&M from tariff payments. But there is little evidence to date that any but the largest small-town schemes are able to cover 
capital maintenance from user fees (Fonseca, et al., 2013). A second area of concern is the total cost of project preparation. In selective instances the BOT schemes themselves may be able to recover O\&M and some of their capital costs. But how do the models compare in terms of development costs? A related area to analyze would be capital expenditure. A review of the technology used for water pumping and treatment would be helpful to identifying the most cost-effective equipment for use in these schemes. This would include an assessment of the low-cost tube well building materials developed by RDA, and the possibility of using technologies like solar power for water pumping, as is now being experimented with in India, Tanzania, and other countries. On the basis of a life-cycle analysis of this kind, the government can then take its own informed decision about service delivery models, and can begin to take ownership of the identified solutions. 


\section{References}

ADB (Asian Development Bank) (2009), "Urban Sector and Water supply and Sanitation in Bangladesh: An Exploratory Evaluation of the Programs of ADB and Other Aid Agencies," Independent Evaluation Department, July.

Ahmad, J., B.N. Goldar, S. Misra, and M. Jakariya. 2003. Willingness to Pay for Arsenic-free, Safe Drinking Water in Bangladesh, WSP South Asia Series, Delhi: Water and Sanitation Program.

Argos, M., et al. (2010), "Arsenic exposure from drinking water, and all-cause and chronic-disease mortalities in Bangladesh (HEALS): a prospective cohort study," The Lancet, Vol. 376, Issue 9737, 252 - 258, 24 July.

Aziz, S.N., K.J. Boyle, and M. Rahman (2006), "Knowledge of Arsenic in Drinkingwater: Risks and Avoidance in Matlab, Bangladesh," Journal of Health, Population, and Nutrition 24(3), 327-335.

Bilu, H.R. (2009), "RDA's water use model gets global recognition," The Daily Star, February 16.

DANIDA (2005), "Water Supply and Sanitation Sector Programme Support (WSSPS) Phase II, HYSAWA Project, Project Document," Government of Bangladesh, Ministry of Foreign Affairs, Denmark, October.

DPHE and JICA (2010), Situation Analysis of Arsenic Mitigation 2009, Dhaka: Department of Public Health Engineering and Japan International Cooperation Agency, June.

Ehrhardt, David, Josses Mugabe, and William Kingdom (2015), "Professionalization Contracts for Small Municipal Water Service Providers in India: Business Model Development," Final Report prepared for the World Bank, June.

Estache, A. And C. Philippe (2012), "The Impact of Private Participation on the Performance of Infrastructure in Developing Countries: Summary of the academic evidence," IFC Economics Notes, No. 2, April.

Fonseca, C., R. Franceys, C. Bachelor, P. McIntyre, A. Klutse, K. Komives, P. Moriarty, A. Naafs, K. Nyarko, C. Pezon, A. Potter, R. Reddy, and M. Snehalatha (2011), "Life-cycle costs approach: Costing sustainable services," WASHCost Briefing Note 1a, The Hague, Netherlands: IRC International Water and Sanitation Centre.

Fonseca, C.; S. Smits, K. Nyarko, A. Naafs, and R. Franceys (2013) "Financing capital maintenance of rural water supply systems: Current practices and future options," WASHCost Working Paper No. 9, The Hague, the Netherlands: IRC International Water and Sanitation Centre.

Fontein, M., J. Webster, and P. Trawick (2020), "Multiple-use water supply systems: do the claims stack up? Evidence from Bangladesh," Waterlines 29(1), January.

Foster, V. and T. Yepes (2006), "Is Cost Recovery a Feasible Objective for Water and Electricity? The Latin America Experience," Policy Research Working Paper 3943, Washington, DC: World Bank. 
Foster, T. (2012), Private Sector Provision of rural Water Services: A Desk Study for Water for People, Denver, CO: Water for People.

Gassner, K., A. Popov, and N. Pushak (2009), Does Private Sector Participation Improve Performance in Electricity and Water Distribution? PPIAF Trends and Policy Options, No. 6, Washington, DC: World Bank.

Hydroconseil and DevCon (2013), "Institutional Options for Small Town Water Supply and Sanitation Services in Bangladesh: Options analysis of appropriate models of WSS service delivery, Deliverable No. 3," Report to the World Bank, May.

Ibrahim, A.K.M. (2004), "Rural Piped Water Supply in Bangladesh: Myth or Reality," People-Centred Approaches to Water and Environmental Sanitation, 30 ${ }^{\text {th }}$ WEDC International Conference, Vientiane, Lao PDR.

Kamruzzaman, A.K.M., I. Said, O. Osman, M. Hasmori, and E. Hossain (2012), "Water Business - Public Private Partnership in rural Bangladesh," Proceedings of the $3^{\text {rd }}$ International Conference on Business and Economic Research, Bandung, Indonesia, 12 March.

Kleemeier, E (2010), Private operators and rural water supplies: A desk review of experience. World Bank Water Papers. Washington, DC: The World Bank.

Kumar, G., I. Lieberman, and Y. Mumssen (2010), "Access to Finance in OutputBased Aid," OBA Working paper Series, Paper No. 11, October.

Marin, P. (2009), Public-Private Partnerships for Urban Water Utilities: A Review of Experiences in Developing Countries, PPIAF Trends and Policy Options, No. 8, Washington, DC: World Bank.

Moriarty, P., S. Smits, J. Butterworth, and R. Franceys (2013), "Trends in rural water supply: Towards a service delivery approach," Water Alternatives 6(3): 329-349.

RWSN (Rural Water Supply Network) (2010), "Myths of the rural water supply sector," Perspectives Paper No. 4, RWSN Executive Steering Committee, St. Gallen: RWSN.

SDF (Social Development Foundation) (2014), "Rural Piped Water Pilot Project," Presentation to the World Bank, 25 March.

Sirtaine, S., M.E. Pinglo, J.L. Guasch, and V. Foster (2005), How Profitable are Infrastructure Concessions in Latin America? Empirical Evidence and Regulatory Implications, PPIAF Trends and Policy Options, No. 2, Washington, DC: World Bank.

Sy, J., R. Warner, and J. Jamieson (2014), Tapping the Markets: opportunities for Domestic Investments in Water and Sanitation for the Poor, Directions in Development, Private Sector Development, Washington, DC: World Bank.

Trémolet, S., M. Scatasta, and P. Borkey (2010), "Innovative Financing mechanisms for the Water Sector," Report of the Working Party on global and Structural Policies, Environment Policy committee, Organisation for Economic Co-operation and Development (OECD), February.

Unb (2008), “\$5m Danish help for rural water schemes,” The Daily Star, July 3. 
World Bank (2003), Project Appraisal Document on a Proposed Credit in the Amount of SDR 13.5 Million (US\$18.24 Million Equivalent) to the People's Republic of Bangladesh for a Social Investment Program Project, Washington, DC: World Bank.

(2004), Project Appraisal Document on a Proposed Grant in the Amount of SDR 27.6 Million (US\$40.0 Million Equivalent) to the People's Republic of Bangladesh for a Water Supply Program Project, Washington, DC: World Bank.

(2007), Implementation Completion and Results Report (IDA-31240 SWTZ-21082) on a Credit in the Amount of SDR 24.2 Million (US\$44.4 Million Equivalent) to Bangladesh for Arsenic Mitigation Water Supply, Washington, DC: World Bank.

(2011a), Implementation Completion and Results Report (IDA-H1010) on a Grant in the Amount of SDR 27.6 Million (US\$ 40.0 Million Equivalent) Subsequently Reduced After Restructuring to the Amount of SDR 11.8 Million (US\$ 18.6 Million Equivalent) to the People's Republic of Bangladesh for a Water Supply Program Project, Washington, DC: World Bank.

(2011b), Implementation Completion and Results Report (Cr. 3740) on a Credit in the Amount of SDR 13.5 Million (US\$18.4 Million Equivalent) to the People's Republic of Bangladesh for a Social Investment Program Project, Washington, DC: World Bank.

(2012), Project Appraisal Document on a Proposed Credit in the Amount of SDR 48.4 Million (US\$75 Million Equivalent) to the People's Republic Of Bangladesh for the Bangladesh Rural Water Supply and Sanitation Project, Washington, DC: World Bank.

WSP (Water and Sanitation Program) (2010), "Learnings from Bangladesh: Experience in Private Provision of Rural Piped Water," Field Note, December, Washington, DC: World Bank.

(2015), "Monitoring Report on 21 Rural Piped Water Schemes under Bangladesh Water Supply and Program Project (BWSPP)," Bangladesh SSDPSP Water Project, Washington, DC: World Bank.

WHO (World Health Organization) (2002), "Arsenic - Mass poisoning on an unprecedented Scale," accessed at www.who.int/features/archives/feature206/en/\# 


\section{Interviews}

\section{Government of Bangladesh}

- Local Government Division (Joint Secretary - Water) Akram Al Hossain, Dhaka, arch 25, 2015

- Department of Public Health Engineering (DPHE) Kazi Abdul Noor, Dhaka, March 30, 2015 Engr. A Kaium, Dhaka, March 30, 2015

- Public Private Partnership (PPP) Office Syed Afsor H Uddin, Dhaka, March 24, 2015

\section{DevConsultants Ltd.}

Tanveer Ahsan, Dhaka, March 22, 2015

\section{Water Tech Ltd.}

Jail D Ahsan, Dhaka, March 22, 2015

\section{Hilful Fuzul}

Rafiqul Islam, Dhaka, March 24, 2015

Social Development Foundation

MIM Zulfiqar, Dhaka, March 25, 2015

AZM Sakhawat Hossain, Dhaka, March 25, 2015

\section{Rural Development Academy (RDA)}

MA Matin, Dhaka, March 25, 2015

\section{Hysawa Fund}

Enamul Kabir, Dhaka, March 24, 2015

\section{BRAC}

Milan Kanti Barua, Dhaka, March 22, 2015

Md Akramul Islam, March 22, 2015

\section{World Bank}

Abdul Motaleb, Dhaka, March 18, 2015

Arif Ahamed, Dhaka, March 18, 2015

Waliul Islam, Dhaka, March 18, 2015

Zahed Khan, Dhaka, March 19, 2015

AKM Abdullah, Dhaka, March 19, 2015

Karin Erika Kemper, phone interview, April 22, 2015.

Khawaga Minnatullah, phone interview, May 12, 2015.

Fook Chuan Eng, Washington DC, May 18, 2015 